\title{
Characterizing the spatiotemporal nitrogen stable isotopic composition of ammonia in vehicle plumes
}

\author{
Wendell W. Walters ${ }^{1,2}$, Linlin Song ${ }^{3,4,5}$, Jiajue Chai ${ }^{1,2}$, Yunting Fang ${ }^{3,4,5}$, Nadia Colombi ${ }^{1, a}$, and \\ Meredith G. Hastings ${ }^{1,2}$ \\ ${ }^{1}$ Department of Earth, Environmental, and Planetary Sciences, Brown University, Providence, RI 02912, USA \\ ${ }^{2}$ Institute at Brown for Environment and Society, Brown University, Providence, RI 02912, USA \\ ${ }^{3}$ CAS Key Laboratory of Forest Ecology and Management, Institute of Applied Ecology, \\ Chinese Academy of Sciences, Shenyang, Liaoning, 110016, China \\ ${ }^{4}$ Key Laboratory of Stable Isotope Techniques and Applications, Shenyang, Liaoning, 110016, China \\ ${ }^{5}$ College of Sources and Environment, University of Chinese Academy of Sciences, Beijing 100049, China \\ ${ }^{\mathrm{a}}$ current address: Department of Earth and Planetary Science, Harvard University, Cambridge, MA 02139, USA
}

Correspondence: Wendell W. Walters (wendell_walters@brown.edu)

Received: 27 February 2020 - Discussion started: 9 March 2020

Revised: 22 July 2020 - Accepted: 6 August 2020 - Published: 9 October 2020

\begin{abstract}
Vehicle emissions have been identified as an important urban source of ammonia $\left(\mathrm{NH}_{3}\right)$. However, there are large uncertainties regarding the contribution of vehicle emissions to urban $\mathrm{NH}_{3}$ budgets, as well as the role of $\mathrm{NH}_{3}$ in spatiotemporal fine particulate matter $\left(\mathrm{PM}_{2.5}\right)$ formation and nitrogen $(\mathrm{N})$ deposition patterns. The $\mathrm{N}$ stable isotopic composition $\left(\delta^{15} \mathrm{~N}\right)$ may be a useful observational constraint to track $\mathrm{NH}_{3}$ emission sources and chemical processing, but previously reported vehicle $\delta^{15} \mathrm{~N}\left(\mathrm{NH}_{3}\right)$ emission signatures have reported a wide range of values, indicating the need for further refinement. Here we have characterized $\delta^{15} \mathrm{~N}\left(\mathrm{NH}_{3}\right)$ spatiotemporal variabilities from vehicle plumes in stationary and on-road measurements in the USA and China using an active $\mathrm{NH}_{3}$ collection technique demonstrated to accurately characterize $\delta^{15} \mathrm{~N}\left(\mathrm{NH}_{3}\right)$ on the order of hourly time resolution. Significant spatial and temporal $\delta^{15} \mathrm{~N}_{\left(\mathrm{NH}_{3}\right)}$ variabilities were observed and suggested to be driven by vehicle fleet composition and influences from $\mathrm{NH}_{3}$ dry deposition on tunnel surfaces. Overall, a consistent $\delta^{15} \mathrm{~N}\left(\mathrm{NH}_{3}\right)$ signature of $6.6 \pm 2.1 \%$ o $(\bar{x} \pm 1 \sigma ; n=80)$ was found in fresh vehicle plumes with fleet compositions typical of urban regions. Our recommended vehicle $\delta^{15} \mathrm{~N}\left(\mathrm{NH}_{3}\right)$ signature is significantly different from previous reports. This difference is due to a large and consistent $\delta^{15} \mathrm{~N}\left(\mathrm{NH}_{3}\right)$ bias of approximately $-15.5 \%$ o between commonly employed passive $\mathrm{NH}_{3}$ collection techniques and the laboratory-tested active $\mathrm{NH}_{3}$ collec-
\end{abstract}

tion technique. This work constrains the $\delta^{15} \mathrm{~N}\left(\mathrm{NH}_{3}\right)$ urban traffic plume signature, which has important implications for tracking vehicle $\mathrm{NH}_{3}$ in urban-affected areas and highlights the importance of utilizing verified collection methods for accurately characterizing $\delta^{15} \mathrm{~N}\left(\mathrm{NH}_{3}\right)$ values.

\section{Introduction}

Atmospheric ammonia $\left(\mathrm{NH}_{3}\right)$ is a critical component of the atmosphere and the global nitrogen $(\mathrm{N})$ cycle (Behera et al., 2013; Galloway et al., 2004). As the primary atmospheric alkaline molecule, $\mathrm{NH}_{3}$ plays an essential role in the neutralization of sulfuric acid $\left(\mathrm{H}_{2} \mathrm{SO}_{4}\right)$ and nitric acid $\left(\mathrm{HNO}_{3}\right)$, leading to the formation of ammonium nitrate $\left(\mathrm{NH}_{4} \mathrm{NO}_{3}\right)$, ammonium bisulfate $\left(\mathrm{NH}_{4} \mathrm{HSO}_{4}\right)$, and ammonium sulfate $\left(\left(\mathrm{NH}_{4}\right)_{2} \mathrm{SO}_{4}\right)$ (Behera and Sharma, 2012). These compounds are the most abundant secondary components of inorganic fine particulate matter $\left(\mathrm{PM}_{2.5}\right)$, which has important implications for air quality, human health, visibility, and global climate change (Behera and Sharma, 2010; Updyke et al., 2012; Wang et al., 2015). Deposition of $\mathrm{NH}_{3}$ and its secondary product, particulate ammonium $\left(\mathrm{pNH}_{4}^{+}\right)$, have critical environmental consequences, including soil acidification (via plant assimilation, nitrification, and $\mathrm{NH}_{3}$ volatilization), eutrophication, and decreased biodiversity in sensitive ecosys- 
tems (Bolan et al., 1991; Erisman et al., 2008; Galloway et al., 2004; Sutton et al., 2008). In recent years, $\mathrm{N}$ deposition in the form of $\mathrm{NH}_{x}\left(=\mathrm{NH}_{3}+\mathrm{pNH}_{4}^{+}\right.$) has come to dominate total inorganic reactive $\mathrm{N}$ deposition across most of the United States ( $\mathrm{Li}$ et al., 2016). To evaluate the influence of $\mathrm{NH}_{3}$ on climate and the environment, an accurate understanding of $\mathrm{NH}_{3}$ atmospheric concentrations, emission sources, and spatiotemporal distributions is critical. However, the quantification of $\mathrm{NH}_{3}$ emission budgets remains uncertain (Clarisse et al., 2009), and recent high-resolution satellite $\mathrm{NH}_{3}$ observations imply that anthropogenic emission inventories are substantially underestimated (Van Damme et al., 2018).

While agricultural activities are known to dominate the emission of $\mathrm{NH}_{3}$, accounting for over $60 \%$ of the global inventory (Bouwman et al., 1997), there are significant spatiotemporal variabilities due to its short atmospheric lifetime that is on the order of several hours to a day and its multitude of emission sources (e.g., Hu et al., 2014). In urban regions, vehicle-derived emissions have been identified as a major $\mathrm{NH}_{3}$ source (Decina et al., 2017; Gong et al., 2011; Li et al., 2006; Livingston et al., 2009; Meng et al., 2011; Nowak et al., 2012; Sun et al., 2014, 2017). Recently, vehicle $\mathrm{NH}_{3}$ emissions have been suggested to be a key driver of $\mathrm{N}$ deposition in urban and urban-affected regions (Fenn et al., 2018). However, relating urban $\mathrm{NH}_{3}$ emission sources to spatiotemporal $\mathrm{N}$ deposition patterns can be challenging due to the variety of potential emission sources that exist in the urban atmosphere including stationary fossil fuel combustion, waste containers, sewerage systems, transport from agricultural areas, and vehicles (Decina et al., 2017, 2020; Gong et al., 2011; Hu et al., 2014; Meng et al., 2011; Saylor et al., 2010; Sun et al., 2014, 2017; Sutton et al., 2000; Whitehead et al., 2007). The $\mathrm{N}$ stable isotopic composition $\left(\delta^{15} \mathrm{~N}\right)$ of $\mathrm{NH}_{3}$ could be a valuable observational constraint to track source contributions and validate model apportionments (Felix et al., 2013, 2017). However, $\delta^{15} \mathrm{~N}\left(\mathrm{NH}_{3}\right)$ source characterization studies are limited, particularly for nonagricultural $\mathrm{NH}_{3}$ emissions (Chang et al., 2016; Felix et al., 2013; Freyer, 1978; Heaton, 1987; Smirnoff et al., 2012); thus, to quantitatively utilize this tracer for $\mathrm{NH}_{3}$ source apportionment requires further improvements in $\delta^{15} \mathrm{~N}\left(\mathrm{NH}_{3}\right)$ source emission signatures and an increased understanding of spatiotemporal variabilities.

Tracking the contribution of vehicle $\mathrm{NH}_{3}$ emissions might be possible using $\delta^{15} \mathrm{~N}\left(\mathrm{NH}_{3}\right)$ (e.g., Felix et al., 2017). However, previous measurements of vehicle $\delta^{15} \mathrm{~N}\left(\mathrm{NH}_{3}\right)$ signatures are limited and have reported a wide range of values from $-17.8 \%$ o to $0.4 \%$ (Chang et al., 2016; Felix et al., 2013; Smirnoff et al., 2012), which overlaps with agriculture-derived $\mathrm{NH}_{3}$ that has been measured to range from $-15.2 \%$ o to $-8.9 \%$ in animal sheds (Heaton, 1987; Freyer, 1978). To quantitatively utilize $\delta^{15} \mathrm{~N}\left(\mathrm{NH}_{3}\right)$ for $\mathrm{NH}_{3}$ source apportionment requires distinguishable isotopic signatures, such that we need to understand the drivers behind the reported large variability in $\delta^{15} \mathrm{~N}\left(\mathrm{NH}_{3}\right)$ from ve- hicle emissions. The previous vehicle $\delta^{15} \mathrm{~N}\left(\mathrm{NH}_{3}\right)$ characterization studies have included tunnel monitoring in the United States (Felix et al., 2013), tunnel monitoring in China (Chang et al., 2016), and near-highway monitoring in Canada (Smirnoff et al., 2012), with reported $\left.\delta^{15} \mathrm{~N} \mathrm{NH}_{3}\right)$ averages $(\bar{x} \pm 1 \sigma)$ of $-3.4 \pm 1.2 \%$ ( $(n=2),-14.2 \pm 2.6 \%$ o $(n=8)$, and $-2.1 \pm 1.9 \%$ o $(n=11)$, respectively. We note that the observed variability may be related to spatiotemporal differences in the vehicle-emitted $\delta^{15} \mathrm{~N}\left(\mathrm{NH}_{3}\right)$, as the studies conducted in the US and Canada have reported relatively consistent values that are higher than those in China, but the factors influencing this potential spatiotemporal $\delta^{15} \mathrm{~N}\left(\mathrm{NH}_{3}\right)$ pattern are unknown (Chang et al., 2016; Felix et al., 2013; Smirnoff et al., 2012). Notably, the reported $\delta^{15} \mathrm{~N}_{\left(\mathrm{NH}_{3}\right)}$ source measurements were conducted using a variety of $\mathrm{NH}_{3}$ capture techniques for offline $\delta^{15} \mathrm{~N}\left(\mathrm{NH}_{3}\right)$ quantification that have included both passive samplers (Chang et al., 2016; Felix et al., 2013) and active collection using a filter pack (Smirnoff et al., 2012). Indeed, it has been shown that different active and passive $\mathrm{NH}_{3}$ collection devices - including a gasscrubbing bubbler, moss bag, shuttle sampler, and diffusion tube - resulted in significant $\delta^{15} \mathrm{~N}\left(\mathrm{NH}_{3}\right)$ differences and variance when sampling the same emission source (Skinner et al., 2006). Thus, there could be inaccuracies in the previously reported $\delta^{15} \mathrm{~N}\left(\mathrm{NH}_{3}\right)$ emission values related to the collection technique used to concentrate ambient $\mathrm{NH}_{3}$ for offline $\delta^{15} \mathrm{~N}\left(\mathrm{NH}_{3}\right)$ characterization.

To improve the $\delta^{15} \mathrm{~N}\left(\mathrm{NH}_{3}\right)$ source inventory for accurate $\mathrm{NH}_{3}$ source apportionment, we need to quantify $\delta^{15} \mathrm{~N}\left(\mathrm{NH}_{3}\right)$ using accurate methods and address spatiotemporal variabilities. In this study, $\delta^{15} \mathrm{~N}\left(\mathrm{NH}_{3}\right)$ was characterized in a variety of integrated vehicle plumes with a combination of stationary and mobile on-road measurements, utilizing a laboratoryverified active collection technique shown to be accurate for $\delta^{15} \mathrm{~N}\left(\mathrm{NH}_{3}\right)$ quantification (Walters and Hastings, 2018). Stationary measurements were conducted during the summer and winter at a near-highway monitoring site in Providence, RI, USA, and within a tunnel in Shenyang, Liaoning, China. A broad spatial survey of on-road mobile measurements was also conducted in the northeastern USA to evaluate the influences of a variety of real-world vehicle fleet compositions and driving modes on the traffic $\delta^{15} \mathrm{~N}\left(\mathrm{NH}_{3}\right)$ signature. Passive $\mathrm{NH}_{3}$ samplers, which have been used in previous $\delta^{15} \mathrm{~N}\left(\mathrm{NH}_{3}\right)$ source characterization studies (Chang et al., 2016; Felix et al., 2013, 2017), were also deployed in the near-highway and tunnel-monitoring campaigns and compared with the active collection technique verified for $\delta^{15} \mathrm{~N}\left(\mathrm{NH}_{3}\right)$ accuracy (Walters and Hastings, 2018). Overall, these data will better define the $\delta^{15} \mathrm{~N}\left(\mathrm{NH}_{3}\right)$ source signature for urban vehicle plumes, with implications for tracking emission contributions to urban atmospheric $\mathrm{NH}_{3}$ concentrations and $\mathrm{N}$ deposition. 


\section{Site description and methods}

\subsection{Sampling sites}

\subsubsection{Near-highway measurements (Providence, RI, USA)}

Stationary measurements were conducted at an airmonitoring station in Providence, RI, USA $\left(41^{\circ} 49^{\prime} 46.0^{\prime \prime} \mathrm{N}\right.$, $71^{\circ} 25^{\prime} 03.0^{\prime \prime} \mathrm{W}$ ), maintained by the Rhode Island Department of Environmental Management (RI-DEM) and Rhode Island Department of Health (RI-DOH) during the summer and winter (Fig. S1 in the Supplement). The airmonitoring station is located $4.62 \mathrm{~m}$ east of the northbound I-95, a major interstate highway with a traffic volume of $\sim 200000$ vehicles $^{-1}$ (HERE Traffic Analysis; https: //company.here.com/automotive/traffic/traffic-analytics/, last access: September 2019), dominated by light-duty gasolinepowered vehicles. Continuous online measurements of $\mathrm{CO}$ (Thermo Scientific 48i) were monitored at the sampling location, and meteorological parameters, including temperature, relative humidity, wind speed, and wind direction, were recorded at the Urban League RI-DEM monitoring site, which is $2.4 \mathrm{~km}$ south of the near-highway site (Fig. S1). Collections of speciated $\mathrm{NH}_{x}$ were conducted using an active sampling technique (denuder-filter pack; described in Sect. 2.2) with $6 \mathrm{~h}$ sampling intervals that included 00:30-06:30, 06:30-12:30, 12:30-18:30, and 18:3000:30 LT during summer (9 to 18 August 2017) and 00:0006:00, 06:00-12:00, 12:00-18:00, and 18:00-00:00 LT during winter (21 January to 1 February 2018). During the sampling periods, $\mathrm{NH}_{x}$ collections were not conducted during precipitation periods (or forecasted precipitation periods) due to the potential role of wet scavenging to alter $\delta^{15} \mathrm{~N}\left(\mathrm{NH}_{3}\right.$ ) (Xiao et al., 2015). $\mathrm{NH}_{3}$ was also collected using a passive sampler (ALPHA), in which $\mathrm{NH}_{3}$ diffuses through a PTFE membrane and accumulates on an acid-coated (5\% citric acid $(w / v)$ in water) cellulose filter (Albet, grade 604, $24 \mathrm{~mm}$ diameter) housed in a protective case. Replicate passive samplers were deployed during the winter for $\mathrm{NH}_{3}$ collection for two separate approximate 1 week collection periods during winter (10-17 and 17-25 February 2018) for a total of four collected samples at the near-highway monitoring site. All samplers were secured on the roof $(\sim 3.85 \mathrm{~m}$ a.g.l. $)$ of the air-monitoring station on the underside of a weatherproof shelter.

\subsubsection{Tunnel measurements (Shenyang, China)}

From 30 October to 5 November in 2018, stationary tunnel measurements were conducted in the middle of an underground tunnel of a north-south expressway in Shenyang, Liaoning Province, China ( $\left.41^{\circ} 48^{\prime} 16.0^{\prime \prime} \mathrm{N}, 123^{\circ} 26^{\prime} 54.0^{\prime \prime} \mathrm{E}\right)$. This tunnel is approximately $2360 \mathrm{~m}$ long and experiences approximately 28804 vehicles $^{-1}$ during the weekday and
26237 vehicles $^{-1}$ during the weekend (data from real-time traffic control system, Shenyang Wu'ai Tunnel Management Co., Ltd.). The tunnel was open to vehicle passage from 05:00 to 23:00, and collections of speciated $\mathrm{NH}_{x}$ were conducted using a denuder-filter pack at $8 \mathrm{~h}$ intervals (approximately $06: 00$ to $14: 00,14: 00$ to $22: 00$, and $22: 00$ to 06:00 LT). Sampling from 22:00 to 06:00 LT included the period that the tunnel was closed to vehicle passage (i.e., 23:00 to 05:00 LT). The denuder-filter pack samplers were mounted on an elevated platform approximately $1.5 \mathrm{~m}$ a.g.l. (Fig. S2). Three ALPHA samplers were also mounted on the elevated platform and simultaneously collected $\mathrm{NH}_{3}$ during the sampling campaign $(\sim 7 \mathrm{~d})$. The relative humidity and temperature within the tunnel were monitored (iButton ${ }^{\circledR}$, DS1923, Wdsen Electronic Technology Co., Ltd.) from 31 October 2018, at 14:00 LT, to the end of the sampling campaign that included measurements for 16 out of the 21 collection periods.

\subsubsection{Mobile on-road measurements (northeastern USA)}

Mobile on-road measurements were conducted in the northeastern USA from 20 to 24 February 2018, for approximately $21 \mathrm{~h}$, and spanned $\sim 2125 \mathrm{~km}$. The mobile laboratory consisted of a pickup truck (Ford F-150) equipped with a denuder-filter sampling device, a $\mathrm{CO}$ analyzer (American Ecotech Serinus 30), a temperature and relative humidity probe (Elitech GSP-6), and a GPS tracking application (Map Plus). The denuder-filter pack samplers were placed in a weatherproof enclosure that was secured in the truck bed ( $\sim 1 \mathrm{~m}$ above the truck bed), and collections were conducted for approximately $1 \mathrm{~h}$ (Fig. S3). Sampling was temporarily ceased during periods in which our vehicle speed was lower than $15 \mathrm{~km} \mathrm{~h}^{-1}$ to limit the possibility of sampling self-emissions. The $\mathrm{CO}$ analyzer was placed inside the truck and kept at a similar temperature to calibration conditions in the laboratory, and an air sampling inlet (PTFE tubing, $6.35 \mathrm{~mm}$ o.d.) was secured to the roof of the truck. Due to the significant power demands of the onboard instruments and collection equipment (i.e., vacuum pump), a gasolinepowered generator (Champion $1200 \mathrm{~W}$ portable generator) was used to power all equipment. The exhaust from the generator was diverted and emitted alongside the truck exhaust.

\subsection{Active collection of $\mathrm{NH}_{x}$}

Active speciated $\mathrm{NH}_{x}$ collection was conducted using a glass honeycomb denuder-filter pack sampling system (ChemComb speciation cartridge) during all campaigns. This collection system has been extensively described for its ability to speciate between reactive inorganic gases and particulate matter for offline concentration determination (Koutrakis et al., 1988, 1993). Briefly, ambient air is drawn into the sampler, and reactive gases are removed under laminar flow 
conditions such that radial mixing can only be achieved via diffusion-based processes. Particulates, with their much lower diffusion velocity compared to gases, cannot migrate to the walls of the denuder during the residence time within the unit and are collected on a downstream filter pack. The samplers are also held vertically to limit the potential for gravitational settling of particles onto the denuder surfaces, such that particulates do not contribute to the denuder extract (Ali et al., 1989). The sampler consisted of a PTFE-coated inlet to minimize reactive gas loss, a $\mathrm{PM}_{2.5}$ impactor plate, a base-coated honeycomb denuder $(2 \%$ carbonate $(w / v)+1 \%$ glycerol $(w / v)$ in $80: 20$ water-methanol $(v / v)$ solution), acid-coated honeycomb denuder $(2 \%$ citric acid $(w / v)+1 \%$ glycerol $(w / v)$ in $20: 80$ water-methanol $(v / v)$ solution) to collect $\mathrm{NH}_{3}$, and a filter pack to collect $\mathrm{pNH}_{4}^{+}$. The basecoated denuder was used to remove atmospheric acids (e.g., $\mathrm{HNO}_{3}, \mathrm{SO}_{2}$, and hydrochloric acid $(\mathrm{HCl})$ ) as a precaution to reduce collection-related gas-particle interactions. Recently, this sampling system has been shown to quantify $\delta^{15} \mathrm{~N}\left(\mathrm{NH}_{3}\right)$ with a precision $( \pm 1 \sigma)$ of $\pm 0.8 \%$ from laboratory experiments and field testing (Walters and Hastings, 2018). The PTFE-coated air inlet $(\sim 4 \mathrm{~cm})$ has been shown to lead to a negligible loss of $\mathrm{NH}_{3}$ and induce insignificant $\delta^{15} \mathrm{~N}\left(\mathrm{NH}_{3}\right)$ fractionation (Koutrakis et al., 1993; Walters and Hastings, 2018). The samplers were directly exposed to ambient air without the use of an additional inlet tubing to prevent the loss of $\mathrm{NH}_{3}$.

In the first measurement campaign (near-highway monitoring in summer of 2017), $\mathrm{pNH}_{4}^{+}$was collected using a single Fluoropore PTFE membrane filter (Millipore, $1.0 \mu \mathrm{m}$ pore, $47 \mathrm{~mm}$ diameter). However, due to potential loss of semivolatile $\mathrm{NH}_{4} \mathrm{NO}_{3}$, all subsequent campaigns utilized a nylon filter (Cole-Parmer, $0.8 \mu \mathrm{m}$ pore, $47 \mathrm{~mm}$ diameter) that has been shown to collect and retain $\mathrm{pNO}_{3}^{-}$quantitatively (Yu et al., 2005). A significant fraction of $\mathrm{pNH}_{4}^{+}$collected on denuded nylon filters may volatilize (Yu et al., 2006), such that a backup acid-coated (5\% citric acid $(w / v)$ in water) cellulose filter (Whatman, $8 \mu \mathrm{m}$ pore, $47 \mathrm{~mm}$ diameter) is used to capture any volatilized $\mathrm{NH}_{3}$ from the collected particles and/or $\mathrm{NH}_{3}$ breakthrough during conditions of denuder saturation (Walters et al., 2019). All collections were conducted at a flow rate of $10 \mathrm{~L} \mathrm{~min}^{-1}$ using a mass-flow controller (Dakota mass-flow controller 6AGC1AL55-10AB2; precision $\pm 1 \%$ ) attached to an oilless vacuum pump (Welch 2546B-01). All denuder and filter preparation, handling, and extraction techniques have been previously described (Walters et al., 2019; Walters and Hastings, 2018) and are summarized in the Supplement (Sect. S1).

\subsection{Concentration and $\delta^{15} \mathrm{~N}\left(\mathrm{NH}_{x}\right)$ isotopic analysis}

The concentrations of the denuder and filter extraction solutions were analyzed using a combination of standardized colorimetry and/or ion chromatography analytical techniques. Colorimetric analysis included measurement of $\left[\mathrm{NH}_{4}^{+}\right]$based on the indophenol blue method with absorbance detection at $625 \mathrm{~nm}$ (e.g., US EPA Method 350.1), as well as $\left[\mathrm{NO}_{2}^{-}\right]$ via diazotization with sulfanilamide dihydrochloride followed by detection of absorbance at $520 \mathrm{~nm}$ (e.g., US EPA Method 353.2) that was automated using a discrete UVvisible spectrophotometer (Westco SmartChem discrete analyzer) at Brown University. These analyses were conducted for all samples collected in the US (i.e., near-highway and mobile measurements). Pooled standard deviations (SDs) $( \pm 1 \sigma)$ of replicate measurements of quality control standards were $\pm 0.35 \mu \mathrm{molL}^{-1}(n=48)$ and $\pm 0.23 \mu \mathrm{molL}^{-1}$ $(n=60)$, and the average relative SDs (RSDs) were $1.3 \%$ and $0.81 \%$ for $\left[\mathrm{NH}_{4}^{+}\right]$and $\left[\mathrm{NO}_{2}^{-}\right]$, respectively. All samples collected in the Shenyang tunnel were analyzed for $\left[\mathrm{NH}_{4}^{+}\right],\left[\mathrm{NO}_{2}^{-}\right],\left[\mathrm{NO}_{3}^{-}\right]$, and $\left[\mathrm{SO}_{4}^{2-}\right]$ using ion chromatography (Dionex ${ }^{\mathrm{TM}}$ ICS-600) at the Institute of Applied Ecology, Chinese Academy of Sciences. Cations were quantified using a Dionex ${ }^{\mathrm{TM}}$ CS12A column and CQ12A guard column with $10 \mathrm{mmolL}^{-1}$ methanesulfonic acid as the eluent. Anions were quantified using a Dionex ${ }^{\mathrm{TM}}$ AS22 column and AQ22 guard column with $4.5 \mathrm{mmol} \mathrm{L}^{-1}$ sodium carbonate and $1.4 \mathrm{mmol} \mathrm{L}^{-1}$ sodium bicarbonate as the eluent. For all quantified ions, the RSD was less than $1.5 \%$. The limit of detection (LOD) values of the quantified ions were no higher than $0.5,0.2,2.0$, and $1.5 \mu \mathrm{mol} \mathrm{L}^{-1}$ for $\left[\mathrm{NH}_{4}^{+}\right],\left[\mathrm{NO}_{2}^{-}\right]$, $\left[\mathrm{NO}_{3}^{-}\right]$, and $\left[\mathrm{SO}_{4}^{2-}\right]$, respectively. The measured $\left[\mathrm{NH}_{4}^{+}\right]$was used to calculate the concentrations of $\mathrm{NH}_{3}$ and $\mathrm{pNH}_{4}^{+}$in the traffic plumes, while $\left[\mathrm{NO}_{2}^{-}\right]$was quantified because it will interfere with nitrogen isotopic analysis of $\mathrm{NH}_{4}^{+}$(Zhang et al., 2007), but $\left[\mathrm{NO}_{2}^{-}\right]$was never measured above the LOD. The gases collected on the base-coated denuder were generally below detection limits and were not reported in this work.

The quantification of $\delta^{15} \mathrm{~N}\left(\mathrm{NH}_{4}^{+}\right)$was performed separately for the acid-coated honeycomb denuder, the particulate filter, and the acid-coated cellulose filter extraction solutions, corresponding to $\mathrm{NH}_{3}, \mathrm{pNH}_{4}^{+}$, and volatilized $\mathrm{pNH}_{4}^{+}$ (and/or $\mathrm{NH}_{3}$ breakthrough during denuder saturation conditions), respectively. Briefly, $\delta^{15} \mathrm{~N}\left(\mathrm{NH}_{4}^{+}\right)$was measured based on an established offline wet-chemistry technique involving hypobromite $\left(\mathrm{BrO}^{-}\right)$oxidation and acetic acid/sodium azide reduction (Zhang et al., 2007), which was conducted for samples with $\left[\mathrm{NH}_{4}^{+}\right]>2 \mu \mathrm{molL}{ }^{-1}$. Samples were diluted to at least $10 \mu \mathrm{molL}^{-1}$ of $\mathrm{NH}_{4}^{+}$and then oxidized to $\mathrm{NO}_{2}^{-}$using $\mathrm{BrO}^{-}$in an alkaline solution as previously described (Zhang et al., 2007). After a reaction time of at least $30 \mathrm{~min}$, the reaction was stopped by $0.4 \mathrm{~mL}$ addition of $0.4 \mathrm{~mol} \mathrm{~L}^{-1}$ sodium arsenite to remove excess $\mathrm{BrO}^{-}$. The concentration of the product $\left(\mathrm{NO}_{2}^{-}\right)$was then measured to confirm the quantitative conversion of $\mathrm{NH}_{4}^{+}$to $\mathrm{NO}_{2}^{-}$. The product $\left(\mathrm{NO}_{2}^{-}\right)$was reduced to nitrous oxide $\left(\mathrm{N}_{2} \mathrm{O}\right)$ using sodium azide buffered in an acetic acid solution based on previously described chemical protocols (McIlvin and Altabet, 2005). 
Samples were then analyzed for their $\left.\delta^{15} \mathrm{~N} \mathrm{~N}_{2} \mathrm{O}\right)$ composition using an automated $\mathrm{N}_{2} \mathrm{O}$ extraction system coupled to a continuous-flow isotope ratio mass spectrometer for $m / z 44,45$, and 46 measurements. These measurements were conducted at Brown University for samples collected within the USA and at the Institute of Applied Ecology, Chinese Academy of Sciences, for samples collected within the Shenyang tunnel. In each batch analysis, samples were calibrated relative to internationally recognized $\mathrm{N}$ isotopic $\mathrm{NH}_{4}^{+}$reference materials. These reference materials underwent the same chemical processing as the samples and were used to correct for isotopic fractionation and blank effects resulting from the chemical conversion of $\mathrm{NH}_{4}^{+}$to $\mathrm{N}_{2} \mathrm{O}$. At Brown University, two international reference materials were used that included IAEA-N2 and USGS25 with $\delta^{15} \mathrm{~N}\left(\mathrm{NH}_{4}^{+}\right)$values of $20.3 \%$ and $-30.3 \%$ o, respectively (Böhlke et al., 1993; Gonfiantini, 1984). Repeated measurements of these reference materials yielded SDs $( \pm 1 \sigma)$ of $\pm 0.65 \%$ o (IAEA-N2; $n=25$ ) and $\pm 0.73 \%$ o (USGS25; $n=25)$ and an overall pooled SD of $\pm 0.69 \%$ o $(n=50)$. At the Institute of Applied Ecology, Chinese Academy of Sciences, three reference materials were used that included IAEA-N1, USGS25, and USGS26 with $\delta^{15} \mathrm{~N}\left(\mathrm{NH}_{4}^{+}\right)$values of $0.4 \%$ o, $-30.3 \%$, and $53.7 \%$ (Böhlke et al., 1993; Gonfiantini, 1984), respectively. These materials had measured SDs of $\pm 0.53 \%$ (IAEA-N1; $n=8$ ), $\pm 0.24 \%$ (USGS25; $n=8$ ), and $\pm 0.45 \%$ (USGS26; $n=8$ ) and an overall pooled $\mathrm{SD}$ of $\pm 0.42 \% o(n=24)$. All $\mathrm{N}$ isotopic compositions are reported relative to reference standards using delta $(\delta)$ notation in units of per mill (\%o).

$\delta(\%)=1000\left(\frac{R_{\text {sample }}}{R_{\text {ref }}}-1\right)$,

where $R$ is the ratio of the heavy to light isotope (i.e., ${ }^{15} \mathrm{~N} /{ }^{14} \mathrm{~N}$ ) for the sample and reference, respectively. Atmospheric nitrogen $\left(\mathrm{N}_{2}\right)$ is the established international deltascale reference for $\mathrm{N}$ isotopic composition.

\subsection{Data analysis}

The targeted analytes were corrected for field blanks, and ambient air concentrations were then calculated based on the volume of sampled air and reported in units of parts per billion by volume $\left(\mathrm{ppb}_{\mathrm{v}}\right)$ and microgram per cubic meter $\left(\mu \mathrm{g} \mathrm{m}^{-3}\right)$ for $\mathrm{NH}_{3}$ and $\mathrm{pNH}_{4}^{+}$, respectively. The effective volume of air sampled by the ALPHA passive sampler was calculated as the following:

$V=D A t / L$,

where $V$ is the volume of sampled air $\left(\mathrm{m}^{3}\right), D$ is the $\mathrm{NH}_{3}$ diffusion constant $\left(=2.09 \times 10^{-5} \mathrm{~m}^{2} \mathrm{~s}^{-1}\right), L$ is the stationary air layer within the sampler $(=0.006 \mathrm{~m}), t$ is the time of exposure (h), and $A$ is the cross sectional area $\left(=3.4636 \times 10^{-4} \mathrm{~m}^{2}\right)$ (from ALPHA Sampler User Instructions).
The method detection limit (MDL) for $\left[\mathrm{NH}_{3}\right]$ and $\left[\mathrm{pNH}_{4}^{+}\right]$determination for the active sampling technique (i.e., denuder-filter pack) was calculated as 3 times the SD of the field blanks. The MDL was reported based on the typical collection times and reported separately for each sampling environment (Table 1). The reported $\left[\mathrm{NH}_{3}\right]$ and $\left[\mathrm{pNH}_{4}^{+}\right]$precisions using the denuder-filter pack sampling device were based on five separate replicate sample collections conducted at the near-highway stationary site and expressed as the relative SD (RSD \%) (Table 1). The error bars of $\left[\mathrm{NH}_{3}\right]$ and $\left[\mathrm{pNH}_{4}^{+}\right]$quantified using the denuder-filter pack in subsequent figures represent the \pm RSD \% when above the MDL. Some collections had $\left[\mathrm{pNH}_{4}^{+}\right]$below the MDL, and these samples were reported as $0.5 \pm 0.5 \mathrm{MDL}$. Multiple passive samplers (i.e., ALPHA) were always simultaneously collected, such that RSD \% was not explicitly determined, and results were reported as $\bar{x} \pm 1 \sigma$ of the multiple collections.

Significant $\mathrm{NH}_{4}^{+}$field blanks were found on the acidcoated honeycomb denuder and the acid-coated cellulose filter. A subset of these blanks was analyzed for $\delta^{15} \mathrm{~N}\left(\mathrm{NH}_{4}^{+}\right)$ and found to have relatively consistent values of $-9.6 \pm$ $1.3 \%_{o}(n=3)$ and $-10.9 \pm 1.4 \%_{\circ}(n=3)$ for the acid-coated honeycomb denuder and acid-coated cellulose filter, respectively. Corrections for $\delta^{15} \mathrm{~N}$ were made based on mass balance to account for the observed blanks as previously described (Walters et al., 2019):

$$
\delta^{15} \mathrm{~N}\left(\mathrm{NH}_{4}^{+}\right)_{\text {sample }}=\frac{-\delta^{15} \mathrm{~N}\left(\mathrm{NH}_{4}^{+}\right)_{\text {total }}\left[\mathrm{NH}_{4}^{+}\right]_{\text {total }}}{\left[\mathrm{NH}_{4}^{+}\right]_{\text {total }}-\left[\mathrm{NH}_{4}^{+}\right]_{\text {blank }}},
$$

Blank $\delta^{15} \mathrm{~N}\left(\mathrm{NH}_{4}^{+}\right)$corrections were made for all samples when the fraction of the field blank $\left(f_{\text {Blank }}=\right.$ $\left.\left[\mathrm{NH}_{4}^{+}\right]_{\text {blank }} /\left[\mathrm{NH}_{4}^{+}\right]_{\text {total }}\right)$ was less than $30 \%$ of the total collected $\mathrm{NH}_{4}^{+}$, as the propagated $\delta^{15} \mathrm{~N}$ uncertainty generally did not exceed $\pm 2.5 \%$ or for this $f_{\text {Blank }}$ value. Samples with an $f_{\text {Blank }}$ that exceeded $30 \%$ were not reported for $\delta^{15} \mathrm{~N}$. This requirement as well as the azide method detection limit (i.e.,

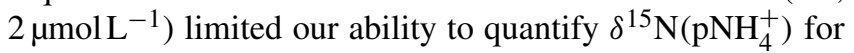
samples collected at the near-highway monitoring site and mobile on-road measurements, such that only $\delta^{15} \mathrm{~N}\left(\mathrm{NH}_{3}\right)$ was reported for the collections conducted in the USA. The collection media blank also impacted the mobile $\delta^{15} \mathrm{~N}\left(\mathrm{NH}_{3}\right)$ measurements, as 6 out of 20 samples had a $f_{\text {Blank }}>30 \%$. Error bars reported for subsequent $\delta^{15} \mathrm{~N}$ values represent the propagated uncertainty that includes the collection uncertainty and the blank contribution. Replicate collected samples at the near-highway site indicated that $\delta^{15} \mathrm{~N}\left(\mathrm{NH}_{3}\right)$ from $\mathrm{NH}_{3}$ collected using an acid-coated denuder had an average reproducibility within $0.8 \%$ o $(n=5)$ (Table 1$)$, consistent with previous field measurements (Walters and Hastings, 2018). 
Table 1. Summary of method detection limit (MDL), pooled relative SDs (RSD), and $\delta^{15} \mathrm{~N}$ reproducibility of $\mathrm{NH}_{3}$ determined from active sampling using a denuder-filter pack (ChemComb speciation cartridge). The MDL is reported in units of $\mathrm{ppb}_{\mathrm{v}}$ for $\mathrm{NH}_{3}$ and $\mu \mathrm{g} \mathrm{m}^{-3}$ for $\mathrm{pNH}_{4}^{+}$. The MDL is reported for each sampling environment, including the near-highway (NH) monitoring location in Providence, RI, USA, during the summer (Summer-NH) and winter (Winter-NH) on-road mobile measurements in the northeastern USA (Mobile) and the tunnel in Shenyang, Liaoning, China (Tunnel).

\begin{tabular}{lcccccc}
\hline \multirow{2}{*}{ Species } & \multicolumn{3}{c}{ MDL $\left(\mathrm{ppb}_{\mathrm{v}}\right.$ or $\left.\mathrm{\mu g} \mathrm{m}^{-3}\right)$} & \multirow{2}{*}{$\mathrm{RSD}(\%)$} & $\delta^{15} \mathrm{~N}$ reproducibility \\
\cline { 2 - 5 } & Summer NH & Winter NH & Mobile & Tunnel & \\
\hline \multicolumn{2}{l}{ Active sampling (denuder-filter pack) } & & & \\
\hline $\mathrm{NH}_{3}$ & 0.088 & 0.147 & 0.415 & 0.170 & 9.8 & $0.8 \% 0$ \\
$\mathrm{pNH}_{4}^{+}$ & 0.090 & 0.234 & 0.093 & 0.118 & 8.5 & N/A $^{*}$ \\
\hline
\end{tabular}

NA: not available. ${ }^{*}$ Separate measurement of $\delta^{15} \mathrm{~N}\left(\mathrm{pNH}_{4}^{+}\right)$was not conducted due to sample mass limitations.

\section{Results}

\subsection{Near-highway measurements (Providence, RI, USA)}

Seasonal $\mathrm{NH}_{x}$ collections at the near-highway monitoring site were performed under a variety of environmental conditions (Table 2). Overall, the near-highway $\left[\mathrm{NH}_{3}\right]$ ranged between 5.8 and $20.2 \mathrm{ppb}_{\mathrm{v}}$ during summer and 2.4 and $20.9 \mathrm{ppb}_{\mathrm{v}}$ during winter at the near-highway monitoring location (Fig. 1a). The average $\left[\mathrm{NH}_{3}\right](\bar{x} \pm 1 \sigma)$ was $14.0 \pm$ $4.0 \mathrm{ppb}_{\mathrm{v}}(n=32)$ and $12.0 \pm 4.8 \mathrm{ppb}_{\mathrm{v}}(n=22)$ for summer and winter, respectively (Table 2), which was not found to be significantly different $(p>0.05)$. Diel $\left[\mathrm{NH}_{3}\right]$ patterns were observed during both summer and winter, with significantly lower values occurring during the night and/or early morning collection period (Table 2 ). The dependence of $\left[\mathrm{NH}_{3}\right]$ on the vector-averaged wind direction is shown in Fig. 2. Overall, the near-highway monitoring site was downwind of I-95 for 51 out of $54 \mathrm{NH}_{x}$ collection periods (Fig. 2). The $\left[\mathrm{NH}_{3}\right]$ was significantly lower when the wind direction indicated the monitoring site was upwind of I-95 compared to when downwind of I-95, with averages of $5.8 \pm 2.7 \mathrm{ppb}_{\mathrm{v}}(n=3)$ and $13.6 \pm 4.2 \mathrm{ppb}_{\mathrm{v}}$, respectively $(p<0.01)$. Strong positive linear correlations were found between $\left[\mathrm{NH}_{3}\right]$ and the mean $[\mathrm{CO}]$ during each collection period during summer $(r=0.736, p<0.01)$ and winter $(r=$ $0.821, p<0.01$ ), with slopes $\left(\mathrm{mol} \mathrm{mol}^{-1}\right.$ ) of $0.025 \pm 0.005$ and $0.027 \pm 0.005$, respectively (Fig. 3). These observed relations between $\left[\mathrm{NH}_{3}\right]$ and $[\mathrm{CO}]$ were similar to previously reported values of $0.031 \pm 0.005$ from on-road measurements in New Jersey and California in the United States using highresolution open-pathway sensors (Sun et al., 2014, 2017), as well as 0.031 to 0.038 based on fitted $\mathrm{NH}_{x}$ and $\mathrm{CO}$ slopes from aircraft measurements in the Californian South Coast Air Basin (Nowak et al., 2012). The similarity of these measurements indicated that the traffic plumes measured in this study were representative of previous literature reports in the USA, and the active collection of $\mathrm{NH}_{3}$ using a denuder-filter

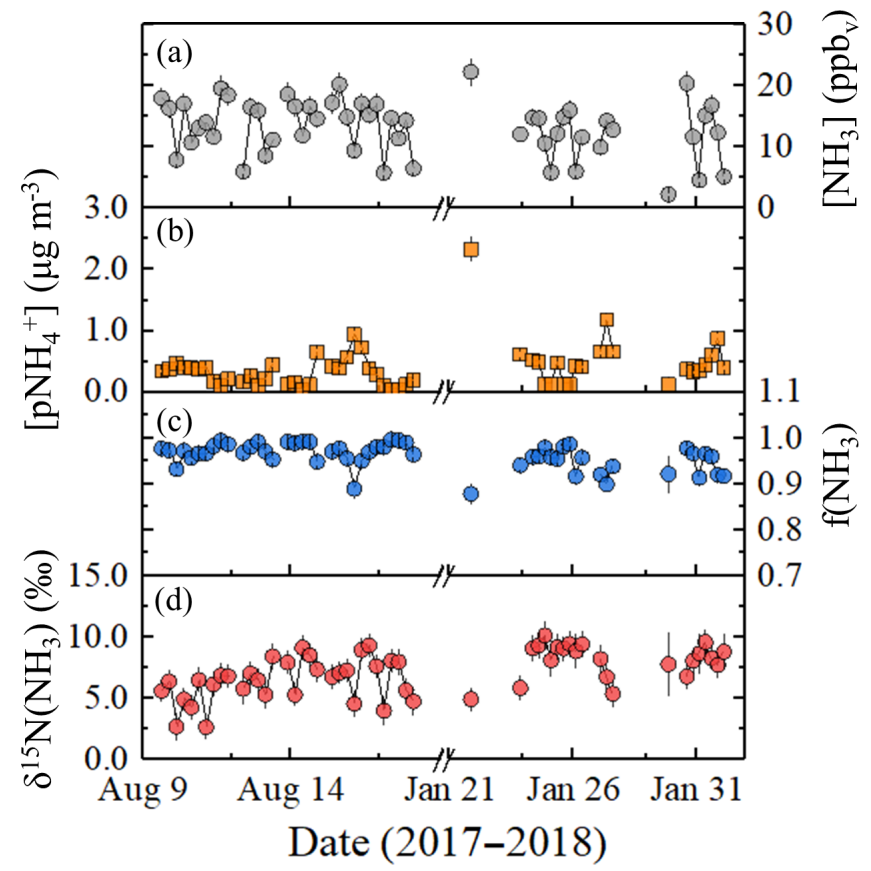

Figure 1. Near-highway (Providence, RI, USA) data summary of (a) $\left[\mathrm{NH}_{3}\right]$, (b) $\left[\mathrm{pNH}_{4}^{+}\right]$, (c) $f\left(\mathrm{NH}_{3}\right)\left(=\left[\mathrm{NH}_{3}\right](\mathrm{mol}) /\left[\mathrm{NH}_{x}\right](\mathrm{mol})\right)$, and (d) $\delta^{15} \mathrm{~N}\left(\mathrm{NH}_{3}\right)$. The $\mathrm{NH}_{x}$ data were generated from an active collection technique using a denuder-filter pack with a collection time of $6 \mathrm{~h}$, and the error bars for concentrations and $\delta^{15} \mathrm{~N}\left(\mathrm{NH}_{3}\right)$ measurements shown as black vertical lines represent the RSD (\%) and propagated error, respectively. The breaks in the $x$ axes separate the summer and winter measurements.

pack sampling technique was suitable for reproducing accurate $\left[\mathrm{NH}_{3}\right]$ under traffic plume environmental conditions.

Roadside $\left[\mathrm{pNH}_{4}^{+}\right.$] ranged from 0.045 to $0.938 \mu \mathrm{g} \mathrm{m}^{-3}$ and from 0.117 to $2.327 \mu \mathrm{g} \mathrm{m}^{-3}$ during summer and winter, respectively (Fig. 1b). The average $\left[\mathrm{pNH}_{4}^{+}\right]$was $0.302 \pm$ $0.208 \mu \mathrm{g} \mathrm{m}^{-3}(n=32)$ and $0.530 \pm 0.468 \mu \mathrm{g} \mathrm{m}^{-3}(n=22)$ during summer and winter, respectively (Table 2 ), which was significantly different $(p<0.05)$. During winter, a $\left[\mathrm{pNH}_{4}^{+}\right]$ 
Table 2. Summary of the near-highway (Providence, RI, USA) environmental conditions including temperature (Temp), relative humidity

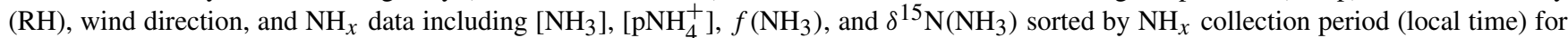
both summer and winter. Data are reported as $\bar{x}( \pm 1 \sigma)$ for each collection period during summer and winter, respectively. The number of collections made during each collection period $(n)$ is indicated.

\begin{tabular}{|c|c|c|c|c|c|c|c|}
\hline $\begin{array}{l}\text { Collection } \\
\text { period }(n)\end{array}$ & $\begin{array}{r}\text { Temp } \\
\left({ }^{\circ} \mathrm{C}\right)\end{array}$ & $\begin{array}{l}\mathrm{RH} \\
(\%)\end{array}$ & $\begin{array}{l}\text { Prevailing wind } \\
\text { direction }\end{array}$ & $\begin{array}{l}{\left[\mathrm{NH}_{3}\right]} \\
\left(\mathrm{ppb}_{\mathrm{v}}\right)\end{array}$ & $\begin{array}{l}{\left[\mathrm{pNH}_{4}^{+}\right]} \\
\left(\mu \mathrm{g} \mathrm{m}^{-3}\right)\end{array}$ & $f\left(\mathrm{NH}_{3}\right)$ & $\begin{array}{c}\delta^{15} \mathrm{~N}\left(\mathrm{NH}_{3}\right) \\
(\% \circ)\end{array}$ \\
\hline \multicolumn{8}{|c|}{ Summer (9 to 18 August) } \\
\hline $00: 30-06: 30(7)$ & $20.1(1.0)$ & $80.5(11.1)$ & WSW & $9.8(3.7)$ & $0.350(0.269)$ & $0.956(0.032)$ & $4.2(1.0)$ \\
\hline $06: 30-12: 30(8)$ & $24.0(1.9)$ & $63.6(10.2)$ & $S$ & $13.4(3.7)$ & $0.301(0.221)$ & $0.973(0.016)$ & $7.3(1.5)$ \\
\hline $12: 30-18: 30(8)$ & $27.4(2.0)$ & $45.1(14.1)$ & SSE & $16.0(3.3)$ & $0.252(0.135)$ & $0.980(0.012)$ & $7.1(1.5)$ \\
\hline 18:30-00:30 (9) & $23.1(1.3)$ & $65.8(13.5)$ & SSW & $15.9(1.8)$ & $0.310(0.183)$ & $0.976(0.015)$ & $6.9(0.7)$ \\
\hline Overall (32) & $23.7(3.0)$ & $63.3(17.4)$ & SSW & $14.0(4.0)$ & $0.302(0.208)$ & $0.972(0.022)$ & $6.4(1.7)$ \\
\hline \multicolumn{8}{|c|}{ Winter (21 January to 1 February) } \\
\hline 00:00-06:00 (5) & $-3.7(2.8)$ & $59.1(10.8)$ & WNW & $6.3(1.7)$ & $0.388(0.173)$ & $0.925(0.017)$ & $8.5(0.3)$ \\
\hline $06: 00-12: 00(5)$ & $-0.8(4.3)$ & $53.6(13.8)$ & WNW & $13.4(1.5)$ & $0.601(0.289)$ & $0.947(0.024)$ & $8.8(1.0)$ \\
\hline $12: 00-18: 00(5)$ & $2.7(4.3)$ & $43.7(12.5)$ & WNW & $16.0(2.7)$ & $0.447(0.191)$ & $0.963(0.015)$ & $7.8(1.5)$ \\
\hline 18:00-00:00 (7) & $0.8(4.3)$ & $61.2(16.0)$ & NW & $12.3(5.2)$ & $0.640(0.739)$ & $0.942(0.036)$ & $7.7(1.7)$ \\
\hline Overall (22) & $-0.2(4.6)$ & $55.0(15.2)$ & WNW & $12.0(4.8)$ & $0.530(0.468)$ & $0.944(0.029)$ & $8.1(1.4)$ \\
\hline
\end{tabular}
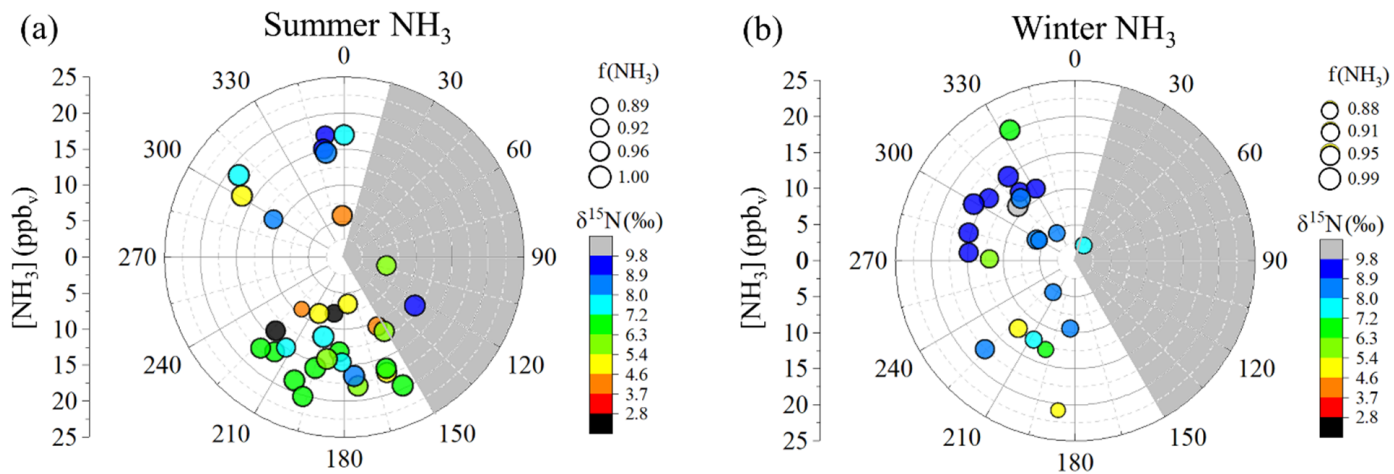

Figure 2. Wind sector analysis of samples collected at the near-highway monitoring site (Providence, $\mathrm{RI}, \mathrm{USA})$ for $\left[\mathrm{NH}_{3}\right]$ (circles) in (a) summer and (b) winter. The data are coded by size for $f\left(\mathrm{NH}_{3}\right)$ and color-coded for $\delta^{15} \mathrm{~N}\left(\mathrm{NH}_{3}\right)$ (\%o). The monitoring location is downwind of I-95 except for wind directions 15 to $150^{\circ}$ (grey shaded region).

outlier of $2.327 \mu \mathrm{g} \mathrm{m}^{-3}$ was identified based on a Grub's $\mathrm{t}$ test $(p<0.05)$. However, even with the removal of this outlier, the seasonal $\left[\mathrm{pNH}_{4}^{+}\right]$average was found to be significantly different $(p<0.05) . \mathrm{NH}_{x}$ speciation was quantified as $f\left(\mathrm{NH}_{3}\right)$ :

$f_{\mathrm{NH}_{3}}=\frac{\left[\mathrm{NH}_{3}\right](\mathrm{mol})}{\left[\mathrm{NH}_{3}+\mathrm{pNH}_{4}^{+}\right](\mathrm{mol})}$.

Overall, $f\left(\mathrm{NH}_{3}\right)$ ranged from 0.889 to 0.996 during summer and from 0.878 to 0.986 during winter (Fig. 1c), indicating that $\mathrm{NH}_{3}$ was the dominant $\mathrm{NH}_{x}$ species during both summer and winter. The average $f\left(\mathrm{NH}_{3}\right)$ was $0.972 \pm 0.022$ $(n=32)$ and $0.944 \pm 0.029(n=22)$ during summer and winter, respectively (Table 2). The average seasonal $f\left(\mathrm{NH}_{3}\right)$ was found to be statistically different $(p<0.05)$, indicating a greater extent of $\mathrm{NH}_{3}$ partitioning to $\mathrm{pNH}_{4}^{+}$during winter. Significant correlations were observed between $f\left(\mathrm{NH}_{3}\right)$ and relative humidity for both summer $(r=-0.533, p<0.01)$ (Fig. S4) and winter $(r=-0.613, p<0.01)$ (Fig. S5).

The measured $\delta^{15} \mathrm{~N}\left(\mathrm{NH}_{3}\right)$ ranged from $2.6 \%$ to $9.3 \%$ o and from $4.9 \%$ to $10.1 \%$ during the summer and winter, respectively (Fig. 1d). The $\delta^{15} \mathrm{~N}\left(\mathrm{NH}_{3}\right)$ averages were $6.4 \pm 1.7 \% \circ(n=32)$ and $8.1 \pm 1.4 \% \circ(n=22)$ during summer and winter, respectively (Table 2 ), which were significantly different $(p<0.05)$. The dependence of $\delta^{15} \mathrm{~N}\left(\mathrm{NH}_{3}\right)$ on the vector-averaged wind direction is shown in Fig. 2. Overall, the $\delta^{15} \mathrm{~N}\left(\mathrm{NH}_{3}\right)$ values were not found to be significantly different when the monitoring site was upwind or downwind of I-95, with averages of $7.6 \pm 1.4 \%$ o $(n=3)$ and $7.1 \pm 1.8 \%$ o $(n=51)$, respectively $(p>0.05)$, which is 


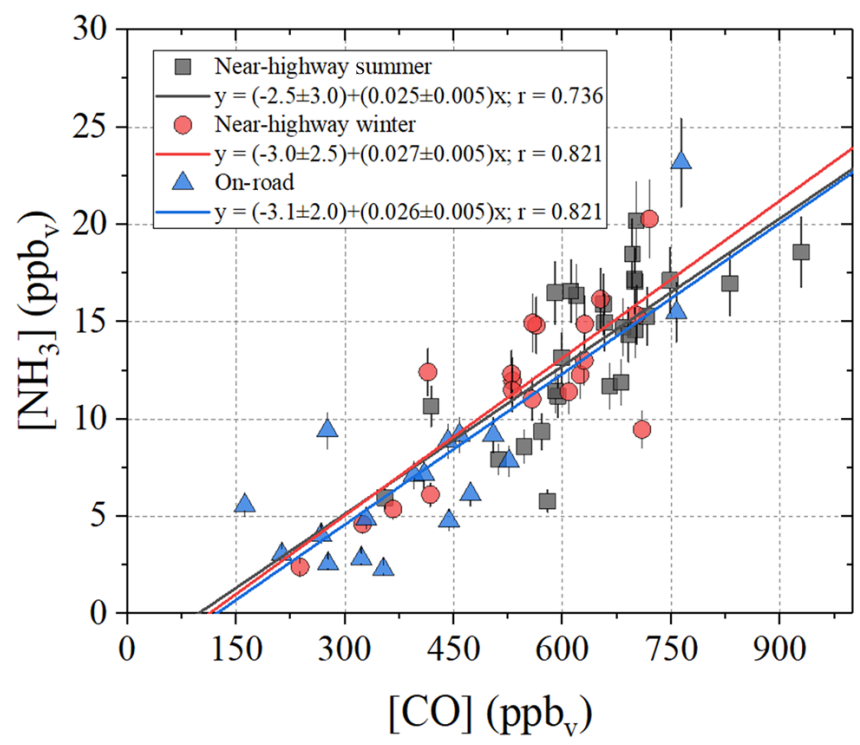

Figure 3. Linear relations between $\left[\mathrm{NH}_{3}\right]$ and $[\mathrm{CO}]$ from the nearhighway (Providence, RI, USA) and mobile on-road (northeastern USA) measurements. The $\left[\mathrm{NH}_{3}\right]$ data were based on acidcoated denuder collection, and the [CO] represents the average of the online-determined concentrations over the collection period. The linear regressions (solid lines) and Pearson's correlation coefficients $(r)$ are provided for each respective measurement location.

likely due to the proximity of the sampling location to air masses significantly influenced by vehicle emissions. No statistical difference was found between the collection period and $\delta^{15} \mathrm{~N}\left(\mathrm{NH}_{3}\right)$ during the winter $(p>0.05)$, but significantly lower $\delta^{15} \mathrm{~N}\left(\mathrm{NH}_{3}\right)$ values were observed during the summer for the night and/or early morning sample (00:30 to $06: 30)(p<0.05)$ (Table 2). Significant correlations between $\delta^{15} \mathrm{~N}\left(\mathrm{NH}_{3}\right)$ and $f\left(\mathrm{NH}_{3}\right)$ were observed for both summer $(r=0.349, p<0.05)$ (Fig. S4) and winter $(r=0.535$, $p<0.05$ ) (Fig. S5). However, these correlations were found to be impacted by influential $f\left(\mathrm{NH}_{3}\right)$ values during the summer and winter of 0.889 and 0.878 , respectively (Figs. S4 and S5). Removing these influential $f\left(\mathrm{NH}_{3}\right)$ observations resulted in an insignificant correlation between $\delta^{15} \mathrm{~N}\left(\mathrm{NH}_{3}\right)$ and $f\left(\mathrm{NH}_{3}\right)$ for both summer $(r=0.300, p>0.05)$ (Fig. S4) and winter $(r=0.378, p>0.05)$ (Fig. S5).

\subsection{Tunnel measurements (Shenyang, Liaoning, China)}

Tunnel temperature and relative humidity conditions remained relatively consistent throughout our sampling campaign and averaged $19.3 \pm 1.6^{\circ} \mathrm{C}$ and $35.4 \pm 6.7 \%$, respectively (Table 3 ). Due to the elevated concentrations in the tunnel, the amount of collected $\mathrm{NH}_{3}$ on the acid-coated honeycomb denuders averaged $406 \pm 125 \mu \mathrm{g}$, indicating the laboratory-determined operative capacity of $\sim 400 \mu \mathrm{g}$ was often exceeded (Walters and Hastings, 2018). The citric acid coated filter collected no more than $275 \mu$ g of $\mathrm{NH}_{3}$, which was within the laboratory-determined operative capacity of at least $350 \mu \mathrm{g}$ (Walters et al., 2019). Thus, our $\mathrm{NH}_{x}$ measurements are expected to be accurate, but there could be uncertainty in the $\mathrm{NH}_{x}$ speciation; this is because the $\mathrm{NH}_{4}^{+}$extracted from the acid-coated denuder and nylon filter will have a low bias due to denuder saturation and $\mathrm{pNH}_{4}^{+}$ volatilization, respectively, and $\mathrm{NH}_{4}^{+}$extracted from the acidcoated filter will derive from both $\mathrm{NH}_{3}$ breakthrough and $\mathrm{NH}_{3}$ volatilized from the nylon filter. Therefore, our concentration results and analysis of samples collected in the Shenyang tunnel will focus on $\left[\mathrm{NH}_{x}\right]$. Overall, $\left[\mathrm{NH}_{x}\right]$ ranged from 64.4 to $210.6 \mathrm{ppb}_{\mathrm{v}}$ and averaged $132.5 \pm 45.8(n=21)$ (Fig. 4a; Table 3 ). An obvious $\left[\mathrm{NH}_{x}\right]$ diel cycle was observed in which higher concentrations occurred during periods when the tunnel was open compared to sampling periods in which the tunnel was closed to vehicle passage, with averages of $136.8 \pm 18.8 \mathrm{ppb}_{\mathrm{v}}(n=7), 181.2 \pm 23.0 \mathrm{ppb}_{\mathrm{v}}(n=7)$, and $79.4 \pm 14.4 \mathrm{ppb}_{\mathrm{v}}(n=7)$ for the $06: 00$ to $14: 00,14: 00$ to 22:00, and 22:00 to 06:00 LT collection periods, respectively (Table 3).

We have estimated $f\left(\mathrm{NH}_{3}\right)$, assuming that the $\mathrm{pNH}_{4}^{+}$in $\mathrm{PM}_{2.5}$ was linked to the $\mathrm{SO}_{4}^{2-}-\mathrm{NO}_{3}^{-}-\mathrm{NH}_{4}^{+}$thermodynamic system and that the influence of other ions (e.g., $\mathrm{Na}^{+}, \mathrm{Ca}^{2+}$, or $\mathrm{Cl}^{-}$) had a negligible impact on the chemistry of this system (Shah et al., 2018). Ion-mass balance was utilized to calculate the expected $\left[\mathrm{pNH}_{4}^{+}\right]$for each collection period based on the measured $\left[\mathrm{pNO}_{3}^{-}\right]$and $\left[\mathrm{pSO}_{4}^{2-}\right]$ (Fig. $4 \mathrm{~b}$ ) from the aqueous filter extracts:

$\left[\mathrm{pNH}_{4}^{+}\right](\mathrm{mol})=\left(2\left[\mathrm{pSO}_{4}^{2-}\right]+\left[\mathrm{pNO}_{3}^{-}\right]\right)(\mathrm{mol})$.

Utilizing the ion-mass balance approach, $f\left(\mathrm{NH}_{3}\right)$ was estimated to range between 0.856 and 0.997 and averaged $0.956 \pm 0.038$ (Fig. 4c; Table 3). $\mathrm{NH}_{x}$ speciation was also estimated using ISORROPIA, which is a gas-aerosol equilibrium partitioning model (Fountoukis and Nenes, 2007; Nenes et al., 1998). Model inputs included the measured $\left[\mathrm{NH}_{x}\right],\left[\mathrm{pNO}_{3}^{-}\right]$, and $\left[\mathrm{pSO}_{4}^{2-}\right]$ and average relative humidity and temperature for each collection period, and the model was run in the forward direction in the metastable state. The $f\left(\mathrm{NH}_{3}\right)$ was then calculated based on the model output of $\left[\mathrm{NH}_{3}\right]$ and $\left[\mathrm{pNH}_{4}^{+}\right]$(Table $\mathrm{S} 1$ in the Supplement). Overall, there was a near-exact agreement in $f\left(\mathrm{NH}_{3}\right)$ between the ion-mass balance and the ISORROPIA approaches, noting that ISORROPIA was not used for the first five collection periods due to the absence of relative humidity and temperature data (Fig. 4c). Overall, this analysis indicated that $\mathrm{NH}_{x}$ in the tunnel was primarily in the form of $\mathrm{NH}_{3}$, consistent with the near-highway stationary observations.

The measured $\delta^{15} \mathrm{~N}$ from $\mathrm{NH}_{4}^{+}$extracted from the acidcoated denuders, nylon filters, and acid-coated filters averaged $6.0 \pm 5.6 \% \circ(n=21), 1.0 \pm 10.7 \% \circ(n=21)$, and $-20.0 \pm 10.1 \%$ o $(n=21)$ (Fig. S6), respectively. These $\delta^{15} \mathrm{~N}$ differences, to some degree, reflect differences in the $\delta^{15} \mathrm{~N}$ of ambient $\mathrm{NH}_{3}$ and $\mathrm{NH}_{4}^{+}$but are difficult to interpret due to 
Table 3. Summary of the Shenyang, China, tunnel data including temperature (Temp), relative humidity $\left(\mathrm{RH}^{2},\left[\mathrm{NH}_{x}\right], f\left(\mathrm{NH}_{3}\right),\left[\mathrm{NH}_{3}\right]\right.$, and $\delta{ }^{15} \mathrm{~N}\left(\mathrm{NH}_{x}\right)$. Data are reported as $\bar{x}( \pm 1 \sigma)$ for each collection period and the overall monitoring period during summer and winter. The number of collections made during each collection period $(n)$ is also indicated.

\begin{tabular}{|c|c|c|c|c|c|}
\hline $\begin{array}{l}\text { Collection } \\
\text { period }(n)\end{array}$ & $\begin{array}{l}\text { Temp } \\
\left({ }^{\circ} \mathrm{C}\right)\end{array}$ & $\begin{array}{l}\mathrm{RH} \\
(\%)\end{array}$ & $\begin{array}{l}{\left[\mathrm{NH}_{x}\right]} \\
\left(\mathrm{ppb}_{\mathrm{v}}\right)\end{array}$ & $f\left(\mathrm{NH}_{3}\right)^{\mathrm{a}}$ & $\begin{array}{c}\delta^{15} \mathrm{~N}\left(\mathrm{NH}_{x}\right)^{\mathrm{b}} \\
(\% \circ)\end{array}$ \\
\hline 06:00-14:00 (7) & $19.2(1.1)$ & $35.2(4.8)$ & $136.8(18.8)$ & $0.959(0.027)$ & $3.6(1.0)$ \\
\hline $14: 00-22: 00(7)$ & $20.5(1.9)$ & $36.2(6.4)$ & $181.2(23.0)$ & $0.973(0.028)$ & $4.8(2.0)$ \\
\hline 22:00-06:00 (7) & $18.3(0.9)$ & $34.7(8.1)$ & $79.4(14.4)$ & $0.937(0.045)$ & $0.1(1.3)$ \\
\hline Overall (21) & $19.3(1.6)$ & $35.4(6.7)$ & $132.5(45.8)$ & $0.956(0.038)$ & $2.9(2.5)$ \\
\hline
\end{tabular}

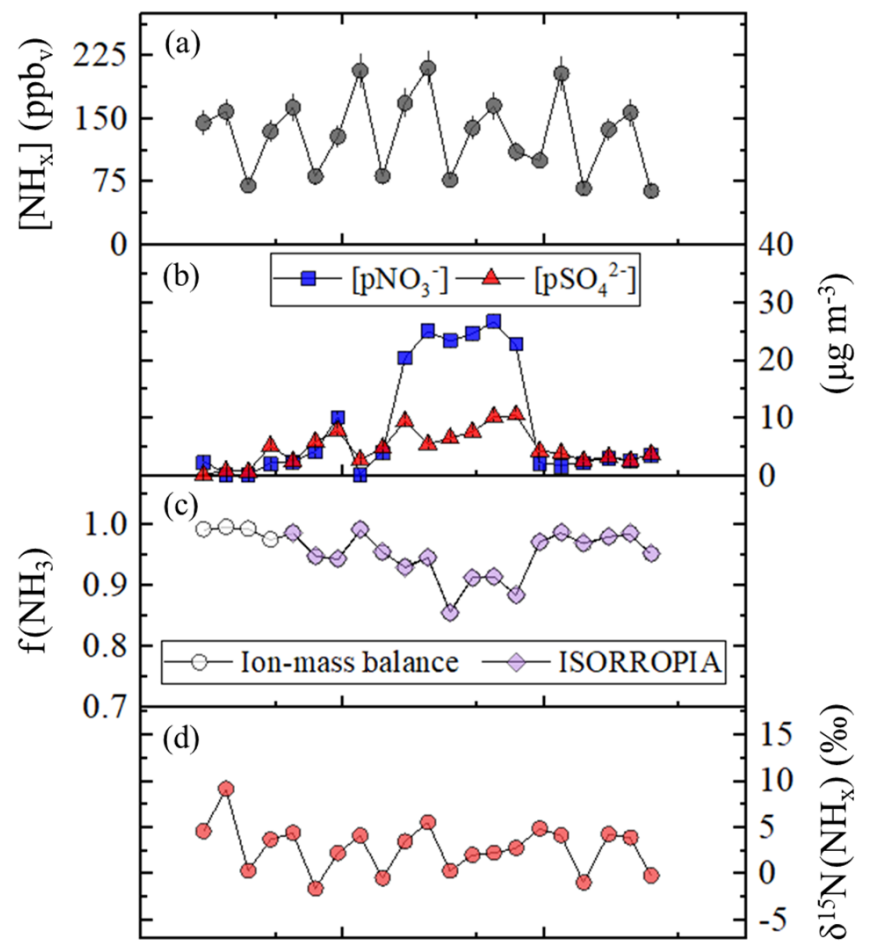

Oct $29 \quad$ Nov $1 \quad$ Nov $4 \quad$ Nov 7

Date (2018)

Figure 4. Tunnel (Shenyang, Liaoning, China) data summary of (a) $\left[\mathrm{NH}_{x}\right]$, (b) concentrations of $\left[\mathrm{pNO}_{3}^{-}\right]$(blue square) and $\left[\mathrm{pSO}_{4}^{2-}\right]$ (red triangle), (c) $f\left(\mathrm{NH}_{3}\right)$ calculated using ion-mass balance (open circle) and modeled using ISORROPIA (purple diamond), and (d) $\delta^{15} \mathrm{~N}\left(\mathrm{NH}_{x}\right)$. The data were generated using a denuder-filter pack with a collection time of approximately $8 \mathrm{~h}$. Error bars for concentrations and $\delta^{15} \mathrm{~N}\left(\mathrm{NH}_{x}\right)$ measurements shown as black vertical lines represent the RSD (\%) and propagated error, respectively. ISORROPIA was not run for five collection periods, due to the absence of relative humidity and temperature data. the ambiguity in $\mathrm{NH}_{x}$ speciation. Since $\mathrm{NH}_{x}$ speciation was not achieved in the tunnel collections due to denuder saturation, our reported isotopic results and analysis will focus on $\delta^{15} \mathrm{~N}\left(\mathrm{NH}_{x}\right)$, with the expectation that it primarily represents $\mathrm{NH}_{3}$. The $\delta^{15} \mathrm{~N}\left(\mathrm{NH}_{x}\right)$ was calculated for each sampling period using mass balance:

$$
\begin{aligned}
\delta^{15} \mathrm{~N}\left(\mathrm{NH}_{x}\right)= & f_{\mathrm{NH}_{4}^{+}-\text {denuder }}, \delta^{15} \mathrm{~N}\left(\mathrm{NH}_{4}^{+}\right)_{\text {denuder }}, \\
& +f_{\mathrm{NH}_{4}^{+}-\text {nylon }} \delta^{15} \mathrm{~N}\left(\mathrm{NH}_{4}^{+}\right)_{\text {nylon }}, \\
& +f_{\mathrm{NH}_{4}^{+} \text {-acid filter }} \delta^{15} \mathrm{~N}\left(\mathrm{NH}_{4}^{+}\right)_{\text {acid filter }},
\end{aligned}
$$

where $f_{\mathrm{NH}_{4}^{+} \text {-denuder }}, f_{\mathrm{NH}_{4}^{+}-\text {nylon }}$, and $f_{\mathrm{NH}_{4}^{+} \text {-acid filter }}$ represent the fractions of $\mathrm{NH}_{4}^{+}$extracted from the denuder, nylon filter, and acid-coated filter, respectively, for each sampling event. Overall, the $\delta^{15} \mathrm{~N}\left(\mathrm{NH}_{x}\right)$ ranged from $-1.6 \%$ to $9.2 \%$ (Fig. $4 \mathrm{~d}$ ) and had a numerical average of $2.9 \pm$ $2.5 \%$ o $(n=21)$ (Table 3$)$. There was a strong diel cycle in $\delta^{15} \mathrm{~N}\left(\mathrm{NH}_{x}\right)$ in which the 22:00 to 06:00 LT collection period that included the period the tunnel was closed to vehicle passage (i.e., 23:00 to 05:00 LT) resulted in a statistically lower $\delta^{15} \mathrm{~N}\left(\mathrm{NH}_{x}\right)$ of $0.1 \pm 1.3 \%$ o $(n=7)$, relative to the $06: 00$ to $14: 00$ and $14: 00$ to $22: 00 \mathrm{LT}$ collection periods that averaged $3.6 \pm 1.0 \% \circ(n=7)$ and $4.8 \pm 2.0 \%$ o $(n=7)$, respectively $(p<0.05)$ (Table 3$)$.

\subsection{Mobile on-road $\mathrm{NH}_{3}$ survey (northeastern USA)}

Overall, the on-road $\left[\mathrm{NH}_{3}\right]$ ranged from 2.3 to $23.2 \mathrm{ppb}_{\mathrm{v}}$ and averaged $7.3 \pm 4.7 \mathrm{ppb}_{\mathrm{v}}(n=20)$ (Fig. 5b). The highest $\left[\mathrm{NH}_{3}\right]$ were found to occur during collection periods near urban cores that included Boston, MA, Providence, RI, New York City, NY, and Washington, DC (Fig. 6a). The on-road $\left[\mathrm{NH}_{3}\right]$ was significantly correlated with [CO] $(r=$ $0.821, p<0.01$ ), and the linear relationship between $\mathrm{NH}_{3}$ and $\mathrm{CO}$ had a slope $\left(\mathrm{NH}_{3}(\mathrm{~mol}): \mathrm{CO}(\mathrm{mol})\right)$ of $0.026 \pm 0.005$ (Fig. 3), which was similar to the near-highway relation of $0.025 \pm 0.005$ and $0.0270 \pm 0.005$, observed during summer and winter, respectively. On-road $\left[\mathrm{NH}_{3}\right]$ was found to be significantly correlated with vehicle speed $(r=-0.673$, 
$p<0.01$ ) (Fig. S7). On-road $\left[\mathrm{pNH}_{4}^{+}\right]$ranged from 0.047 to $0.710 \mu \mathrm{g} \mathrm{m}^{-3}$ (Fig. 5c) and averaged $0.204 \pm 0.176 \mu \mathrm{g} \mathrm{m}^{-3}$ $(n=20) . \mathrm{NH}_{x}$ speciation indicated that $\mathrm{NH}_{3}$ was the dominant species, which is consistent with our stationary observations, as $f\left(\mathrm{NH}_{3}\right)$ ranged from 0.800 to 0.987 (Fig. 5d) and averaged $0.934 \pm 0.050(n=20)$.

On-road $\delta^{15} \mathrm{~N}\left(\mathrm{NH}_{3}\right)$ ranged from $-3.0 \%$ to $10.1 \%$ o (Fig. 5e) and averaged $5.7 \pm 3.5 \%$ o $(n=14)$. On-road $\delta^{15} \mathrm{~N}\left(\mathrm{NH}_{3}\right)$ was not found to be significantly correlated with $f\left(\mathrm{NH}_{3}\right) \quad(r=0.249, p>0.05)$ or average vehicle speed $(r=-0.179, p>0.05)$ (Fig. S7). Spatial mapping of $\delta^{15} \mathrm{~N}\left(\mathrm{NH}_{3}\right)$ indicated the highest values near urban cores (Fig. 6b). Each collection period was categorized as either a trucking or highway route using the percentage of annual average daily truck traffic contributions to annual average daily traffic (U.S. Dept of Transportation, 2013) similar to that previously described (Miller et al., 2017). Routes on our on-road measurements with diesel trucks that comprised at least $25 \%$ of the annual average daily traffic and at least a yearly average of 8500 diesel trucks per day were identified (U.S. Dept of Transportation, 2013), which were located on rural highways typically outside of urban areas. This categorization technique was used to qualitatively identify differences in vehicle fleet compositions during our measurements since realtime vehicle count data were not collected. Two sampling collection periods were identified as a trucking route, including (1) from outside Harrisburg, PA, to New Smithville, PA, along I-81 and I-78 and (2) from Kirkwood, PA, to Colliersville, NY, along I-81 and I-88. Though the number of measurements conducted on trucking routes was limited in this case study, the average on-road $\delta^{15} \mathrm{~N}\left(\mathrm{NH}_{3}\right)$ values on highway and trucking routes were $6.9 \pm 1.9 \%(n=12)$ and $-1.5 \pm 1.6 \%$ o $(n=2)$, respectively, which were found to be significantly different $(p<0.01)$.

\subsection{Comparison between active and passive $\mathrm{NH}_{3}$ collection}

A comparison between the active and passive collection of $\mathrm{NH}_{3}$ for concentration and $\delta^{15} \mathrm{~N}\left(\mathrm{NH}_{3}\right)$ characterization is summarized in Table 4 . The active collection sampling technique resulted in $\left[\mathrm{NH}_{3}\right]$ of $12.0 \pm 1.2 \mathrm{ppb}_{\mathrm{v}}$ and $127.1 \pm$ $12.5 \mathrm{ppb}_{\mathrm{v}}$ over the entire winter near-highway and Shenyang tunnel sampling campaigns, respectively. These concentrations were calculated from the total collected $\mathrm{NH}_{4}^{+}$over the sampling campaign divided by the total volume of collected air for each respective campaign, and the reported uncertainty represents the RSD of the active collection technique of $9.8 \%$. We note that $\left[\mathrm{NH}_{3}\right]$ in the Shenyang tunnel determined using the denuder-filter pack was not measured directly but was calculated from the measured $\left[\mathrm{NH}_{x}\right]$ and estimated $f\left(\mathrm{NH}_{3}\right)$. The passive collection resulted in $\left[\mathrm{NH}_{3}\right]$ values of $11.6 \pm 1.4 \mathrm{ppb}_{\mathrm{v}}(n=4)$ and $124 \pm 3.6 \mathrm{ppb}_{\mathrm{v}}(n=3)$ during winter at the near-highway monitoring location and in the Shenyang tunnel, respectively, which was in close agreement with the active collection technique. The massweighted $\delta^{15} \mathrm{~N}\left(\mathrm{NH}_{x}\right)$ values using the active collection technique were $8.0 \pm 1.1 \%$ and $3.5 \pm 0.8 \%$ o during winter at the near-highway monitoring location and in the Shenyang tunnel, respectively, where the uncertainty represents the propagated error (Table 4). We note that the tunnel $\delta^{15} \mathrm{~N}\left(\mathrm{NH}_{3}\right)$ technically represents $\delta^{15} \mathrm{~N}\left(\mathrm{NH}_{x}\right)$; however, due to the elevated estimated $f\left(\mathrm{NH}_{3}\right), \delta^{15} \mathrm{~N}\left(\mathrm{NH}_{x}\right) \approx \delta^{15} \mathrm{~N}\left(\mathrm{NH}_{3}\right)$. The passive $\mathrm{NH}_{3}$ collection technique resulted in an average $\delta^{15} \mathrm{~N}\left(\mathrm{NH}_{3}\right)$ of $-7.7 \pm 0.1 \%$ o $(n=4)$ and $-11.7 \pm 0.3 \%$ o $(n=$ 3 ) during winter at the near-highway monitoring location and in the Shenyang tunnel, respectively, which was found to be significantly different from the $\delta^{15} \mathrm{~N}\left(\mathrm{NH}_{3}\right)$ measured using the active collection for each sampling campaign $(p<0.01)$. The $\delta^{15} \mathrm{~N}\left(\mathrm{NH}_{3}\right)$ difference values between passive and active collection were calculated to be $-15.7 \pm 1.1 \%$ and $-15.2 \pm 0.9 \%$ o during winter at the near-highway monitoring location and in the tunnel in Shenyang China, respectively (Table 4), indicating a consistent $\delta^{15} \mathrm{~N}\left(\mathrm{NH}_{3}\right)$ offset between the active and passive sampling collection techniques.

\section{Discussion}

\subsection{Traffic-plume $\delta^{15} \mathrm{~N}\left(\mathrm{NH}_{3}\right)$ variability}

Here we assess the drivers behind the $\delta^{15} \mathrm{~N}\left(\mathrm{NH}_{3}\right)$ variabilities measured within each sampling campaign, including the seasonal difference measured at the near-highway monitoring site, the temporal variation observed during summer at the near-highway site and the Shenyang tunnel, and the spatial patterns observed from the on-road measurements. We

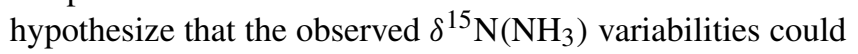
be related to (1) $f\left(\mathrm{NH}_{3}\right)$ partitioning, (2) $\mathrm{NH}_{3}$ dry deposition, (3) background $\mathrm{NH}_{3}$ contributions, and/or (4) vehicle fleet composition differences.

Previously, it has been theoretically estimated and shown from field observations and laboratory studies that isotopic $\mathrm{N}$ equilibrium and reactions between $\mathrm{NH}_{3}$ and $\mathrm{NH}_{4}^{+}$can scramble the ${ }^{14} \mathrm{~N}$ and ${ }^{15} \mathrm{~N}$ distributions between these molecules, leading to the preferential partitioning of ${ }^{15} \mathrm{~N}$ into $\mathrm{NH}_{4}^{+}$ (Kawashima and Ono, 2019; Savard et al., 2017; Urey, 1947; Walters et al., 2018). A significant positive correlation between $f\left(\mathrm{NH}_{3}\right)$ and $\delta^{15} \mathrm{~N}\left(\mathrm{NH}_{3}\right)$ during both summer and winter was observed at the near-highway monitoring location, which is consistent with influences from $\mathrm{N}$ isotopic equilibrium reactions. However, the $\delta^{15} \mathrm{~N}\left(\mathrm{NH}_{3}\right)$ and $f\left(\mathrm{NH}_{3}\right)$ relations were affected by a single influential $f\left(\mathrm{NH}_{3}\right)$ value during both summer and winter, and removal of these points

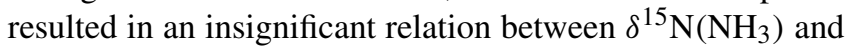
$f\left(\mathrm{NH}_{3}\right)$ (Figs. $\mathrm{S} 4$ and $\mathrm{S} 5$ ). The temporal tunnel variability is not likely to be driven by $f\left(\mathrm{NH}_{3}\right)$ partitioning influences as the estimated $f\left(\mathrm{NH}_{3}\right)$ was not found to be significantly different between periods when the tunnel was open or closed $(p>0.05)$, indicating a significant change in $\mathrm{NH}_{3}$ and 

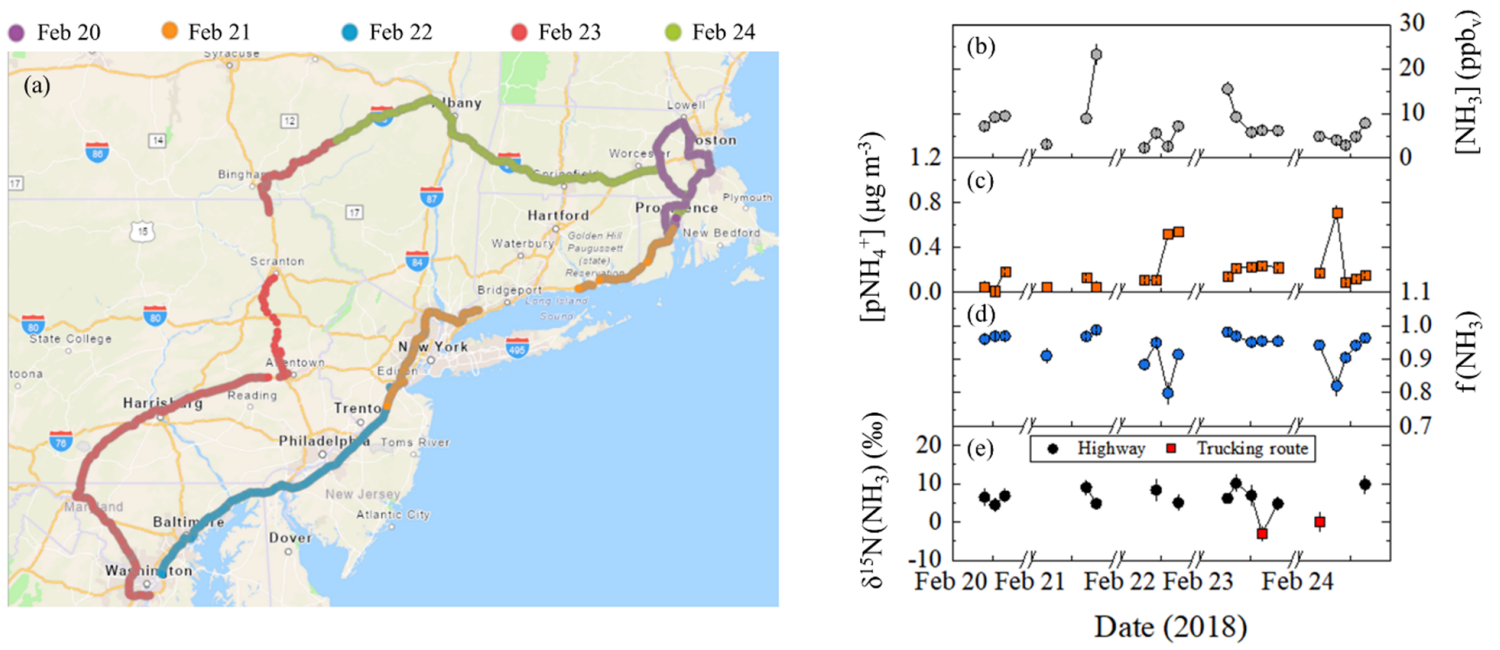

Figure 5. Mobile on-road (northeastern USA) measurements including (a) spatial mapping of measurement path sorted by date and data summary of (b) $\left[\mathrm{NH}_{3}\right]$, (c) $\left[\mathrm{pNH}_{4}^{+}\right]$, (d) $f\left(\mathrm{NH}_{3}\right)\left(=\left[\mathrm{NH}_{3}\right](\mathrm{mol}) /\left[\mathrm{NH}_{x}\right](\mathrm{mol})\right)$, and (e) $\delta^{15} \mathrm{~N}\left(\mathrm{NH}_{3}\right)$ for highway (black circle) and trucking routes (red square). The $\mathrm{NH}_{x}$ data were generated using a denuder-filter pack with a collection time of approximately $1 \mathrm{~h}$, and the error bars for concentrations and $\delta^{15} \mathrm{~N}\left(\mathrm{NH}_{3}\right)$ measurements shown as black vertical lines represent the RSD (\%) and propagated error, respectively. The breaks in the $x$ axes separate breaks in the mobile measurements. Image (a) was created using ArcGIS Copyright ${ }^{\odot} 1995-2019$ Esri. $^{-}$

(a)

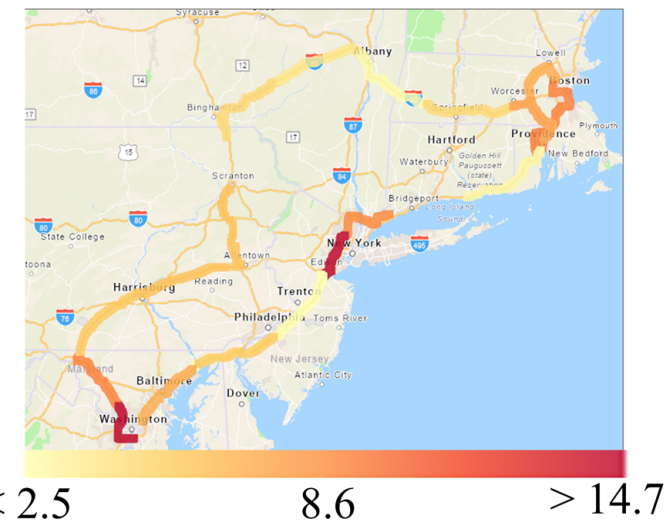

(b)

$\delta^{15} \mathrm{~N}\left(\mathrm{NH}_{3}\right)(\%)$

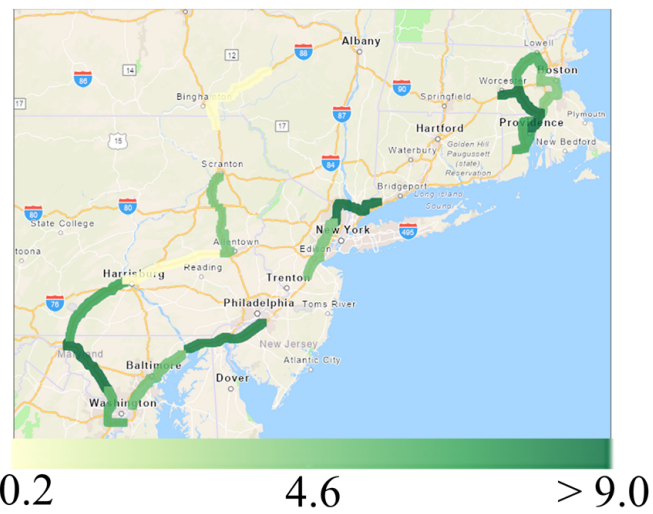

Figure 6. Spatial maps of (a) mean $\left[\mathrm{NH}_{3}\right]\left(\mathrm{ppb}_{\mathrm{v}}\right)$ and (b) $\delta^{15} \mathrm{~N}\left(\mathrm{NH}_{3}\right)(\%$ ) from on-road collections in the northeastern USA. Each color represents one concentration or isotope measurement for $\mathrm{NH}_{3}$ collected over a highway segment at an approximate $1 \mathrm{~h}$ resolution using an acid-coated denuder. Note that there are fewer reported $\delta^{15} \mathrm{~N}\left(\mathrm{NH}_{3}\right)$ values than $\left[\mathrm{NH}_{3}\right]$, because some samples had an elevated blank (i.e., $f_{\text {Blank }}>30 \%$ ) and were not measured for $\delta^{15} \mathrm{~N}\left(\mathrm{NH}_{3}\right)$. Images were created using ArcGIS Copyright ${ }^{\circledR}$ 1995-2019 Esri.

$\mathrm{pNH}_{4}^{+}$partitioning did not occur during these periods. Thus, we do not expect $f\left(\mathrm{NH}_{3}\right)$ partitioning and $\mathrm{NH}_{3}$ reactive sink to have played a significant role in the $\delta^{15} \mathrm{~N}\left(\mathrm{NH}_{3}\right)$ variability observed at the various sampling sites. We note that the influence of $\mathrm{N}$ isotopic exchange reactions on $\delta^{15} \mathrm{~N}\left(\mathrm{NH}_{3}\right)$ depends on the degree of $\mathrm{NH}_{3}$ and $\mathrm{pNH}_{4}^{+}$partitioning. Typically, $f\left(\mathrm{NH}_{3}\right)$ was observed to be $>0.934$, which would limit the influence of equilibrium exchange reactions to alter the measured $\delta^{15} \mathrm{~N}\left(\mathrm{NH}_{3}\right)$ values. We also note that there is an equilibration time needed before $\mathrm{N}$ isotopic equilibrium between $\mathrm{NH}_{3}$ and $\mathrm{pNH}_{4}^{+}$is achieved, but this rate is currently unknown. Thermodynamic gas-fine-aerosol equilibrium has been calculated to have an equilibration time on the order of tens of minutes to several hours, depending on ambient conditions and particle characteristics (Meng and Seinfeld, 1996). Assuming a similar equilibration rate for $\mathrm{N}$ isotopic exchange between $\mathrm{NH}_{3}$ and $\mathrm{pNH}_{4}^{+}$would indicate that complete $\mathrm{N}$ isotopic equilibrium would likely not be achieved near $\mathrm{NH}_{3}$ emission sources, which is consistent with our observations.

$\mathrm{NH}_{3}$ dry deposition was not expected to contribute to the observed variability in the well-ventilated sampling conditions at the near-highway monitoring location and the onroad measurements. These measurements were conducted 
Table 4. Summary of $\left[\mathrm{NH}_{3}\right]$ and $\delta^{15} \mathrm{~N}\left(\mathrm{NH}_{3}\right)$ from the passive and active collection of $\mathrm{NH}_{3}$ at the winter near-highway and Shenyang stationary monitoring locations.

\begin{tabular}{lrr|rrr}
\hline Location & \multicolumn{2}{c|}{$\left[\mathrm{NH}_{3}\right]\left(\mathrm{ppb}_{\mathrm{v}}\right)$} & \multicolumn{3}{c}{$\delta^{15} \mathrm{~N}\left(\mathrm{NH}_{3 / x}\right)(\% o)$} \\
\cline { 2 - 6 } & Passive & Active & Passive & Active & Shift $^{\mathrm{a}}$ \\
\hline Winter near-highway & $11.6 \pm 1.4$ & $12.0 \pm 1.2$ & $-7.7 \pm 0.1$ & $8.0 \pm 1.1$ & $-15.7 \pm 1.1$ \\
Shenyang tunnel & $124 \pm 3.6$ & $127.1 \pm 12.5$ & $-11.7 \pm 0.3$ & $3.5 \pm 0.8^{\mathrm{b}}$ & $-15.2 \pm 0.9$ \\
\hline &
\end{tabular}

close to the emitted $\mathrm{NH}_{3}$ (e.g., typically within $5 \mathrm{~m}$ at the near-highway monitoring site), which should have minimized $\mathrm{NH}_{3}$ loss via dry deposition (Asman et al., 1998). However, $\mathrm{NH}_{3}$ dry deposition may have played an important role under the closed sampling environment of the tunnel and may explain the observed $\delta^{15} \mathrm{~N}\left(\mathrm{NH}_{x}\right)$ temporal variability with higher values observed when the tunnel was open $(4.2 \pm 1.7 \%$ o, $n=14)$ compared to samples collected during periods when the tunnel was closed to traffic $(0.1 \pm 1.3 \%$, $n=7$ ) (Table 3). Previously, lower $\mathrm{NH}_{3}$ emission ratios were reported from traffic plumes in tunnels relative to on-road highway measurements, which was concluded to result from contributions of $\mathrm{NH}_{3}$ dry deposition on the tunnel surfaces (Sun et al., 2017). If $\mathrm{NH}_{3}$ dry deposition is influenced by $\mathrm{N}$ isotopic equilibrium reactions between $\mathrm{NH}_{3}$ and the surface deposited $\mathrm{NH}_{4}^{+}$, this would have resulted in $\mathrm{NH}_{3}$ depleted in ${ }^{15} \mathrm{~N}$ as it is removed from the atmosphere, resulting in lower $\delta^{15} \mathrm{~N}\left(\mathrm{NH}_{3}\right)$ values (Walters et al., 2018). Indeed, a previous $\mathrm{NH}_{3}$ absorption-desorption study on minerals has shown the preferential removal of ${ }^{15} \mathrm{NH}_{3}$ from the gaseous phase, with the degree of ${ }^{15} \mathrm{~N}$ depletion of the gaseous $\mathrm{NH}_{3}$ dependent upon the adsorbed $\mathrm{NH}_{3}$ amount (Sugahara et al., 2017). Thus, as the traffic plume ages in the absence of fresh emissions, we would expect $\mathrm{NH}_{3}$ dry deposition influences and the potential for $\mathrm{N}$ isotopic exchange reactions between the air and tunnel surface to be most significant, which might explain the lower $\delta^{15} \mathrm{~N}\left(\mathrm{NH}_{x}\right)$ values observed during periods when the tunnel was closed. Dry deposition of $\mathrm{NH}_{3}$ during the day in the tunnel could have also impacted the measured $\delta^{15} \mathrm{~N}\left(\mathrm{NH}_{3}\right)$ values, but the constant emission of $\mathrm{NH}_{3}$ likely resulted in nonequilibrium conditions, such that $\mathrm{N}$ isotopic equilibrium between the ambient $\mathrm{NH}_{3}$ and surface deposited $\mathrm{NH}_{4}^{+}$would not have been fully achieved.

Background $\mathrm{NH}_{3}$ contributions are important to identify as a possible driver of $\delta^{15} \mathrm{~N}\left(\mathrm{NH}_{3}\right)$ variability. At the nearhighway monitoring site, wind sector analysis found no statistical difference in $\delta^{15} \mathrm{~N}\left(\mathrm{NH}_{3}\right)$ when sorted by wind direction for either summer or winter (Fig. 2). This indicates that transport from local $\mathrm{NH}_{3}$ point sources other than vehicle emissions played a minor role in the seasonal $\delta^{15} \mathrm{~N}\left(\mathrm{NH}_{3}\right)$ difference. Additionally, the similar seasonal relations between
$\left[\mathrm{NH}_{3}\right]$ and $[\mathrm{CO}]$ at the near-highway monitoring site (Fig. 3) indicate that seasonal variations in background $\mathrm{NH}_{3}$ influences at the near-highway monitoring site were minor. While dilution by background air into the Shenyang tunnel during the periods when the tunnel was closed to traffic should be considered a driver of the temporal $\delta^{15} \mathrm{~N}\left(\mathrm{NH}_{x}\right)$ variability, the average $\left[\mathrm{NH}_{x}\right]$ and $f\left(\mathrm{NH}_{3}\right)$ values were not consistent with significant mixing in of background air. When the tunnel was closed, $\left[\mathrm{NH}_{x}\right]$ averaged $79.4 \pm 14.4 \mathrm{ppb}_{\mathrm{v}}(\mathrm{Ta}-$ ble 3), which is elevated compared to urban background $\left[\mathrm{NH}_{3}\right]$ measurements previously reported from a megacity in China (Beijing) during winter of $5.22 \pm 3.75 \mu \mathrm{g} \mathrm{m}^{-3}$ (or $6.9 \pm 4.9 \mathrm{ppb}_{\mathrm{v}}$ ) (Ianniello et al., 2010). Additionally, $f\left(\mathrm{NH}_{3}\right)$ was elevated during the collection period that the tunnel was closed, averaging $0.937 \pm 0.045$ (Table 3 ), consistent with local emissions rather than contributions from background air that tends to have a lower $f\left(\mathrm{NH}_{3}\right)$ value such as reported to be typically below 0.6 during November based on data collected from Beijing, China (Zhang et al., 2018). Thus, we do not expect the background $\mathrm{NH}_{3}$ contribution to have played a significant role in the tunnel temporal $\delta^{15} \mathrm{~N}\left(\mathrm{NH}_{x}\right)$ variability. Furthermore, we do not expect background $\mathrm{NH}_{3}$ contributions to have played a significant role in the spatial $\delta^{15} \mathrm{~N}\left(\mathrm{NH}_{3}\right)$ variability observed from the on-road measurements in the northeastern USA. While lower $\delta^{15} \mathrm{~N}\left(\mathrm{NH}_{3}\right)$ values in non-urban regions might be consistent with an increased contribution from background agricultural emissions, which tend to have a low $\delta^{15} \mathrm{~N}\left(\mathrm{NH}_{3}\right)$ signature (e.g., $-31 \%$ o to $-14 \%$; Hristov et al., 2011), we expect these temperature-dependent emissions to be minimal during the winter when the on-road measurements were conducted.

Vehicle fleet compositions could have a strong influence on the measured $\delta^{15} \mathrm{~N}\left(\mathrm{NH}_{3}\right)$ variabilities if gasoline- and diesel-powered engines, which utilize different types of $\mathrm{NO}_{x}$ reduction technologies that lead to $\mathrm{NH}_{3}$ emissions (SuarezBertoa and Astorga, 2018), have different $\delta^{15} \mathrm{~N}\left(\mathrm{NH}_{3}\right)$ emission signatures. Categorization of our on-road collection routes into highway routes and trucking routes resulted in statistically significantly different $\delta^{15} \mathrm{~N}\left(\mathrm{NH}_{3}\right)$ values of $6.9 \pm$ $1.9 \% \circ(n=12)$ and $-1.5 \pm 1.6 \% \circ(n=2)$, respectively, supporting the idea that the $\delta^{15} \mathrm{~N}\left(\mathrm{NH}_{3}\right)$ spatial variation was 
influenced by fleet composition. This would also be consistent with previous findings that vehicle fleet composition was the main driver of spatial on-road variability observed for $\delta^{15} \mathrm{~N}\left(\mathrm{NO}_{x}\right)$ (Miller et al., 2017). Vehicle fleet $\mathrm{NH}_{3}$ emissions driven by reduction technologies may have also influenced the seasonal $\delta^{15} \mathrm{~N}\left(\mathrm{NH}_{3}\right)$ difference observed at the near-highway monitoring location. Under cold ambient conditions of $-7^{\circ} \mathrm{C}$, diesel-powered vehicles equipped with the selective catalytic reduction (SCR) technology were reported to have minimal emission of $\mathrm{NH}_{3}$. In comparison, gasolinepowered vehicles equipped with a three-way catalytic converter (TWCC) were reported to have increased $\mathrm{NH}_{3}$ emissions relative to warmer conditions at $23^{\circ} \mathrm{C}$ (Suarez-Bertoa and Astorga, 2018). Vehicle fleet composition may also explain the significantly lower $\delta^{15} \mathrm{~N}\left(\mathrm{NH}_{3}\right)$ values during the summer night and/or early morning collection period at the near-highway monitoring site (Table 2). Vehicle fleet composition was not monitored in this study, but a previous study has reported relatively higher truck traffic compared to gasoline vehicles from near-highway measurements during the night and/or early morning before morning rush hour (Wang et al., 2018). A lower $\delta^{15} \mathrm{~N}\left(\mathrm{NH}_{3}\right)$ signature from diesel emissions compared to gasoline, as supported by our on-road measurements, would explain both the seasonal differences in $\delta^{15} \mathrm{~N}\left(\mathrm{NH}_{3}\right)$ and the temporal $\delta^{15} \mathrm{~N}\left(\mathrm{NH}_{3}\right)$ variability observed primarily during summer. To date, there are neither direct tailpipe measurements of $\delta^{15} \mathrm{~N}\left(\mathrm{NH}_{3}\right)$ from gasolineand diesel-powered vehicle nor an explanation for the expected $\delta^{15} \mathrm{~N}\left(\mathrm{NH}_{3}\right)$ signatures of vehicle-derived emissions. Future work is needed to evaluate direct tailpipe $\delta^{15} \mathrm{~N}\left(\mathrm{NH}_{3}\right)$ signatures from gasoline- and diesel-powered vehicles to test our hypothesis. We note that while there was a statistically significant seasonal difference in the measured $\delta^{15} \mathrm{~N}\left(\mathrm{NH}_{3}\right)$ at the near-highway monitoring site, the absolute difference of $\sim 1.7 \%$ was small.

\subsection{Comparison between active and passive $\mathrm{NH}_{3}$ collection}

A comparison between active and passive sampling was conducted to evaluate the performance of the varying $\mathrm{NH}_{3}$ collection techniques. Overall, remarkably similar $\left[\mathrm{NH}_{3}\right]$ values were determined using the active (i.e., denuder-filter pack) and passive (i.e., ALPHA) sampling techniques (Table 4). The finding of similar $\left[\mathrm{NH}_{3}\right]$ values between passive (ALPHA) and active sampling of $\mathrm{NH}_{3}$ is consistent with previous comparisons (Day et al., 2012; Pan et al., 2020) and provides support that passive collection of $\mathrm{NH}_{3}$ may be a convenient approach for spatial documentation of near-surface $\left[\mathrm{NH}_{3}\right]$.

While the two sampling techniques produced consistent $\left[\mathrm{NH}_{3}\right]$, significant differences in $\delta^{15} \mathrm{~N}\left(\mathrm{NH}_{3}\right)$ were observed. The mass-weighted $\delta^{15} \mathrm{~N}\left(\mathrm{NH}_{3}\right)$ values using the active sampling technique were $8.0 \pm 1.1 \%$ and $3.5 \pm 0.8 \%$, while the values using the passive sampling technique were $-7.7 \pm 0.1 \% \circ(n=4)$ and $-11.7 \pm 0.3 \% \circ(n=3)$ at the near- highway site (winter) and in the Shenyang tunnel, respectively (Table 4). The measured traffic-derived $\delta^{15} \mathrm{~N}\left(\mathrm{NH}_{3}\right)$ values via the passive sampler were similar to previous measurements utilizing a similar sampling approach that included measurements in a tunnel in the USA and a tunnel in China with reported values of $-3.4 \pm 1.2 \% \circ(n=2)$ (Felix et al., 2013) and $-14.2 \pm 2.6 \%$ o $(n=8)$ (Chang et al., 2016), respectively. While our passive $\delta^{15} \mathrm{~N}\left(\mathrm{NH}_{3}\right)$ values were generally consistent with previous reports, there are large offsets between the passive and active sampling techniques that were calculated to be $-15.7 \pm 1.1 \%$ and $-15.2 \pm 0.9 \%$ at the near-highway site and in the Shenyang tunnel, respectively (Table 4). These $\delta^{15} \mathrm{~N}\left(\mathrm{NH}_{3}\right)$ offsets between passive and active $\mathrm{NH}_{3}$ collection techniques are in agreement with a value of $-15.4 \%$ observed from urban background measurements conducted in Beijing, which has been concluded to be due to a diffusive isotope fractionation (Pan et al., 2020). Overall, the large $\delta^{15} \mathrm{~N}\left(\mathrm{NH}_{3}\right)$ offsets observed between passive and active $\mathrm{NH}_{3}$ collection and the potential $\delta^{15} \mathrm{~N}\left(\mathrm{NH}_{3}\right)$ bias in the passive collection of $\mathrm{NH}_{3}$ have several important implications. The majority of reported $\delta^{15} \mathrm{~N}\left(\mathrm{NH}_{3}\right)$ source signatures have been characterized using passive sampling techniques and might be biased by approximately $-15.5 \%$ under the environmental conditions during our sampling periods. These previous measurements could potentially be corrected, but further characterization of the passive sampler $\delta^{15} \mathrm{~N}\left(\mathrm{NH}_{3}\right)$ offset is needed.

\subsection{Urban traffic plume $\delta^{15} \mathrm{~N}\left(\mathrm{NH}_{3}\right)$ signature}

The measured $\delta^{15} \mathrm{~N}\left(\mathrm{NH}_{3}\right)$ traffic plume signatures utilizing the active sampling technique demonstrate an overall range from $-3.0 \%$ to $10.1 \%$ (Fig. 7). Our analysis indicated that $\delta^{15} \mathrm{~N}\left(\mathrm{NH}_{3}\right)$ variability was influenced by fleet composition and $\mathrm{NH}_{3}$ dry deposition in aged vehicle plumes measured in a tunnel. Thus, for deriving an urban traffic plume $\delta^{15} \mathrm{~N}\left(\mathrm{NH}_{3}\right)$ signature, we have considered measurements conducted under fresh plume conditions and on or near highway measurements as representative of urban vehicle $\mathrm{NH}_{3}$ emissions. These observations included the nearhighway measurements conducted during both summer and winter, the mobile on-road measurements conducted on highways, and the Shenyang tunnel during operation. While there are $\delta^{15} \mathrm{~N}\left(\mathrm{NH}_{3}\right)$ differences between sampling environments for this subset of observations (Fig. 7), the absolute difference in the mean $\delta^{15} \mathrm{~N}\left(\mathrm{NH}_{3}\right)$ was quite small (generally within $\sim 3 \%$ o ) and may reflect actual differences in urban vehicle fleet compositions. Overall, the constrained observations assumed to be representative of urban vehicle emissions reduces the $\delta^{15} \mathrm{~N}\left(\mathrm{NH}_{3}\right)$ variability with a range of $2.1 \%$ o to $10.1 \%$ (Fig. 7). The constrained $\delta^{15} \mathrm{~N}\left(\mathrm{NH}_{3}\right)$ has a combined numerical average of $6.6 \pm 2.1 \%$ o $(n=80)$ (Fig. 7), which was found to not significantly differ from a normal distribution (Kolmogorov-Smirnov test of normality, $p=0.528$ ), 
and it is suggested to be the urban vehicle-derived traffic plume $\delta^{15} \mathrm{~N}\left(\mathrm{NH}_{3}\right)$ source signature.

The recommended $\delta^{15} \mathrm{~N}\left(\mathrm{NH}_{3}\right)$ vehicle-derived traffic signature of $6.6 \pm 2.1 \%$ o $(n=80)$ has a narrower range and higher value than previously reported vehicle signatures of $-17.8 \%$ o to $0.4 \%$ (Chang et al., 2016; Felix et al., 2013; Smirnoff et al., 2012). The difference between the recommended $\delta{ }^{15} \mathrm{~N}\left(\mathrm{NH}_{3}\right)$ vehicle-derived source signature and previous reports by Chang et al. (2016) and Felix et al. (2013) was found to be caused by a $\delta^{15} \mathrm{~N}\left(\mathrm{NH}_{3}\right)$ bias from passive $\mathrm{NH}_{3}$ collection that was suggested to be driven by a diffusion isotope effect. The recommended $\delta^{15} \mathrm{~N}\left(\mathrm{NH}_{3}\right)$ vehiclederived source signature was also found to be statistically different from a previous report that actively sampled $\mathrm{NH}_{3}$ using a filter pack collection system, which reported an average $\delta^{15} \mathrm{~N}\left(\mathrm{NH}_{3}\right)$ of $-2.1 \pm 1.9 \%$ (Smirnoff et al., 2012). Differences between our recommended $\delta^{15} \mathrm{~N}\left(\mathrm{NH}_{3}\right)$ value and previous reports by Smirnoff et al. (2012) are difficult to identify and may be related to differences in vehicle fleet compositions. Additionally, we note that this difference may be related to the potential for a positive sampling artifact associated with filter pack collection using a particulate filter and subsequent acid-coated filter for separate $\mathrm{pNH}_{4}^{+}$and $\mathrm{NH}_{3}$ collection, respectively, as volatilization of the collected $\mathrm{pNH}_{4}^{+}$could have resulted in a $\mathrm{NH}_{3}$ collection bias (Yu et al., 2006). Indeed, previous laboratory experiments have shown that $\mathrm{NH}_{3}$ volatilized from $\mathrm{NH}_{4}$ and $\mathrm{NO}_{3}$ particles collected from filters have a $\delta^{15} \mathrm{~N}\left(\mathrm{NH}_{3}\right)$ value lower than the $\delta^{15} \mathrm{~N}\left(\mathrm{pNH}_{4}^{+}\right)$by $28.6 \pm 2.7 \%$ (Walters et al., 2019). Thus, $\mathrm{pNH}_{4}^{+}$volatilization could have artificially lowered the reported $\delta^{15} \mathrm{~N}\left(\mathrm{NH}_{3}\right)$ value and may explain the lower $\delta^{15} \mathrm{~N}\left(\mathrm{NH}_{3}\right)$ values reported in Smirnoff et al. (2012) compared to our results.

\section{Conclusions}

We characterized the $\delta^{15} \mathrm{~N}\left(\mathrm{NH}_{3}\right)$ signatures from a variety of temporal and spatial traffic-derived plumes utilizing a laboratory-verified active collection technique demonstrated to reflect accurate $\delta^{15} \mathrm{~N}\left(\mathrm{NH}_{3}\right)$ values. Overall, our measurements indicate a $\delta^{15} \mathrm{~N}\left(\mathrm{NH}_{3}\right)$ range of $-3.0 \%$ to $10.1 \%$ o from vehicle-derived plumes representing a variety of driving conditions and fleet compositions that included stationary measurements conducted in Providence, RI, USA, and Shenyang, Liaoning, China, and mobile on-road measurements performed in the northeastern USA. These $\delta^{15} \mathrm{~N}\left(\mathrm{NH}_{3}\right)$ values were found to be higher than previous reports of traffic-derived measurements that ranged between $-17.8 \%$ o and $0.4 \%$. Our results indicate that the majority of these previously reported lower values were due to a $\delta^{15} \mathrm{~N}\left(\mathrm{NH}_{3}\right)$ collection bias of approximately $-15.5 \%$ associated with passive $\mathrm{NH}_{3}$ collection, highlighting the critical need to utilize accurate $\delta{ }^{15} \mathrm{~N}\left(\mathrm{NH}_{3}\right)$ collection techniques.
Significant spatial and temporal $\delta^{15} \mathrm{~N}\left(\mathrm{NH}_{3}\right)$ variabilities were observed in the seasonal and summer diel measurements conducted at the near-highway monitoring site, in aged traffic plumes in the Shenyang tunnel, and along rural trucking routes in the northeastern USA. Vehicle fleet composition was suggested to drive significant $\delta^{15} \mathrm{~N}\left(\mathrm{NH}_{3}\right)$ variability, as suspected higher diesel $\mathrm{NH}_{3}$ emissions during summer relative to winter and mobile measurements conducted on trucking routes were found to result in lower $\delta^{15}\left(\mathrm{NH}_{3}\right)$ values, which likely reflects differences in $\mathrm{NH}_{3}$ production via three-way catalytic converter and selective catalytic reduction technologies. Additionally, physical processing associated with $\mathrm{NH}_{3}$ dry deposition was suspected of having lowered the observed $\delta^{15} \mathrm{~N}\left(\mathrm{NH}_{3}\right)$ values in the tunnel when vehicle passage was ceased. The reactive $\mathrm{NH}_{3}$ sink associated with $\mathrm{pNH}_{4}^{+}$formation was found to play a minor role in the $\delta^{15} \mathrm{~N}\left(\mathrm{NH}_{3}\right)$ variability due to elevated $f\left(\mathrm{NH}_{3}\right)$. Accounting for these influences, our results constrain the $\delta^{15} \mathrm{~N}\left(\mathrm{NH}_{3}\right)$ signature from urban traffic-derived fresh plume emissions to $6.6 \pm 2.1 \%$ o $(\bar{x} \pm 1 \sigma ; n=80)$. In addition to $\delta^{15} \mathrm{~N}\left(\mathrm{NH}_{3}\right)$ characterization, our measurements demonstrate elevated $\mathrm{NH}_{3}$ emissions from vehicle plumes and a strong relationship between $\left[\mathrm{NH}_{3}\right]$ and $[\mathrm{CO}]\left(\mathrm{mol} \mathrm{mol}^{-1}\right)$ with fitted slopes of $0.025 \pm 0.005,0.027 \pm 0.005$, and $0.026 \pm 0.005$ for summer near-highway, winter near-highway, and on-road measurements, respectively, which are in agreement with recent measurements in other regions. Overall, our results highlight the significance of traffic-derived $\mathrm{NH}_{3}$ emissions and demonstrate the potential to use $\delta^{15} \mathrm{~N}\left(\mathrm{NH}_{3}\right)$ to track its contributions to chemistry and $\mathrm{N}$ deposition budgets.

The results of this study have important implications for evaluating $\mathrm{NH}_{3}$ budgets, particularly in urban regions. The measured $\delta^{15} \mathrm{~N}\left(\mathrm{NH}_{3}\right)$ traffic signature $(6.6 \pm 2.1 \%$, $n=80)$ is unique as it is the only source that has a reported positive $\delta^{15} \mathrm{~N}\left(\mathrm{NH}_{3}\right)$ value. Thus, $\delta^{15} \mathrm{~N}\left(\mathrm{NH}_{3}\right)$ may be a useful tracer to evaluate the contribution of traffic-derived emissions in urban regions and to evaluate the connection between urban $\mathrm{NH}_{3}$ emissions and its role in $\mathrm{PM}_{2.5}$ formation. Our demonstrated approach for utilizing a laboratory-verified technique with potential for hourly time resolution is applicable for constraining other important $\mathrm{NH}_{3}$ emission sources and to produce a consistent database of $\delta^{15} \mathrm{~N}_{\left(\mathrm{NH}_{3}\right)}$ source signature values. Future work is needed to accurately characterize and improve upon the $\delta^{15} \mathrm{~N}\left(\mathrm{NH}_{3}\right)$ source inventory and evaluate potential fractionation influences associated with $\mathrm{NH}_{x}$ plume aging and deposition.

Data availability. Data presented in this article are available on the Brown Digital Repository at https://doi.org/10.26300/q3h4-7s93 (Walters, 2020).

Supplement. The supplement related to this article is available online at: https://doi.org/10.5194/acp-20-11551-2020-supplement. 


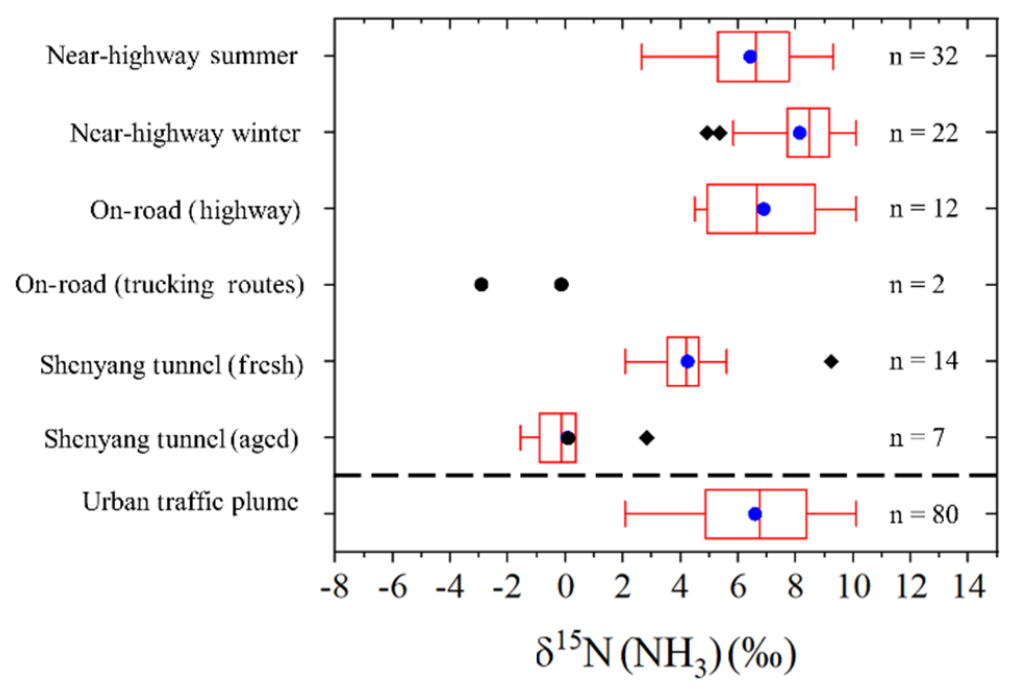

Figure 7. Box and whisker plot summarizing the distribution (lower extreme, lower quartile, median (blue circle), upper quartile, upper extreme, and outliers (black diamond)) of $\delta^{15} \mathrm{~N}\left(\mathrm{NH}_{3}\right)$ measurements from near-highway, on-road, and tunnel sampling. The "Urban traffic plume" category represents the combination of $\delta^{15} \mathrm{~N}\left(\mathrm{NH}_{3}\right)$ measurements from the near-highway, on-road (highway), and Shenyang tunnel (fresh) sampling. No statistical summary is provided for "On-road (trucking routes)", due to the limited number of samples in this category.

Author contributions. WWW, LS, JC, YF, and MGH designed varying aspects of the field sampling plan. WWW, LS, JC, and NC were involved in carrying out the field measurements. WWW and LS conducted all laboratory analyses of data. WWW prepared the article with contributions from all co-authors.

Competing interests. The authors declare that they have no conflict of interest.

Acknowledgements. Wendell W. Walters acknowledges support from an Atmospheric and Geospace Sciences National Science Foundation Postdoctoral Fellowship during this study. We thank Ruby Ho, Joseph Orchardo, Yihang Duan, and many others for sampling and laboratory assistance. We are grateful to Paul Theroux of RI-DEM/RI-DOH for access and support at the RI-DEM air-monitoring site and for providing data. from these sites for our analyses.

Financial support. This research has been supported by the National Science Foundation, Division of Atmospheric and Geospace Sciences (grant nos. 1624618 and 1351932), the National Key R\&D Program (grant no. 2017YFC0212704), the National Research Program for Key Issues in Air Pollution Control (grant no. DQGG0105-02), and the Institute at Brown for Environment and Society (internal grant no. GR300123).

Review statement. This paper was edited by Steven Brown and reviewed by two anonymous referees.

\section{References}

Ali, Z., Thomas, C. L. P., and Alder, J. F.: Denuder tubes for sampling of gaseous species. A review, Analyst, 114, 759-769, 1989.

Asman, W. A., Sutton, M. A., and Schjørring, J. K.: Ammonia: emission, atmospheric transport and deposition, New Phytol., 139, 27-48, 1998.

Behera, S. N. and Sharma, M.: Investigating the potential role of ammonia in ion chemistry of fine particulate matter formation for an urban environment, Sci. Total Environ., 408, 3569-3575, 2010.

Behera, S. N. and Sharma, M.: Transformation of atmospheric ammonia and acid gases into components of $\mathrm{PM}_{2.5}$ : an environmental chamber study, Environ. Sci. Pollut. R., 19, 1187-1197, 2012.

Behera, S. N., Sharma, M., Aneja, V. P., and Balasubramanian, R.: Ammonia in the atmosphere: a review on emission sources, atmospheric chemistry and deposition on terrestrial bodies, Environ. Sci. Pollut. R., 20, 8092-8131, 2013.

Bohlke, J. K., Gwinn, C. J., and Coplen, T. B.: New Reference Materials for Nitrogen-Isotope-Ratio Measurements, Geostandard. Newslett., 17, 159-164, 1993.

Bolan, N. S., Hedley, M. J., and White, R. E.: Processes of soil acidification during nitrogen cycling with emphasis on legume based pastures, Plant Soil, 134, 53-63, 1991.

Bouwman, A. F., Lee, D. S., Asman, W. A. H., Dentener, F. J., Van Der Hoek, K. W., and Olivier, J. G. J.: A global high-resolution emission inventory for ammonia, Global Biogeochem. Cy., 11, 561-587, 1997.

Chang, Y., Liu, X., Deng, C., Dore, A. J., and Zhuang, G.: Source apportionment of atmospheric ammonia before, during, and after the 2014 APEC summit in Beijing using stable nitrogen isotope signatures, Atmos. Chem. Phys., 16, 11635-11647, https://doi.org/10.5194/acp-16-11635-2016, 2016. 
Clarisse, L., Clerbaux, C., Dentener, F., Hurtmans, D., and Coheur, P.-F.: Global ammonia distribution derived from infrared satellite observations, Nat. Geosci., 2, 479-483, 2009.

Day, D. E., Chen, X., Gebhart, K. A., Carrico, C. M., Schwandner, F. M., Benedict, K. B., Schichtel, B. A., and Collett, J. L.: Spatial and temporal variability of ammonia and other inorganic aerosol species, Atmos. Environ., 61 (Supplement C), 490-498, 2012.

Decina, S. M., Templer, P. H., Hutyra, L. R., Gately, C. K., and Rao, P.: Variability, drivers, and effects of atmospheric nitrogen inputs across an urban area: emerging patterns among human activities, the atmosphere, and soils, Sci. Total Environ., 609, 1524-1534, 2017.

Decina, S. M., Hutyra, L. R., and Templer, P. H.: Hotspots of nitrogen deposition in the world's urban areas: a global data synthesis, Front. Ecol. Environ., 18, 92-100, 2020.

Erisman, J. W., Sutton, M. A., Galloway, J., Klimont, Z., and Winiwarter, W.: How a century of ammonia synthesis changed the world, Nat. Geosci., 1, 636-639, 2008.

Felix, D. J., Elliott, E. M., Gish, T. J., McConnell, L. L., and Shaw, S. L.: Characterizing the isotopic composition of atmospheric ammonia emission sources using passive samplers and a combined oxidation-bacterial denitrifier approach, Rapid Commun. Mass Sp., 27, 2239-2246, 2013.

Felix, J. D., Elliott, E. M., and Gay, D. A.: Spatial and temporal patterns of nitrogen isotopic composition of ammonia at U.S. ammonia monitoring network sites, Atmos. Environ., 150 (Supplement C), 434-442, 2017.

Fenn, M. E., Bytnerowicz, A., Schilling, S. L., Vallano, D. M., Zavaleta, E. S., Weiss, S. B., Morozumi, C., Geiser, L. H., and Hanks, K.: On-road emissions of ammonia: An underappreciated source of atmospheric nitrogen deposition, Sci. Total Environ., 625, 909-919, 2018.

Fountoukis, C. and Nenes, A.: ISORROPIA II: a computationally efficient thermodynamic equilibrium model for $\mathrm{K}^{+}-$ $\mathrm{Ca}^{2+}-\mathrm{Mg}^{2+}-\mathrm{NH}_{4}^{+}-\mathrm{Na}^{+}-\mathrm{SO}_{4}^{2-}-\mathrm{NO}_{3}^{-}-\mathrm{Cl}^{-}-\mathrm{H}_{2} \mathrm{O}$ aerosols, Atmos. Chem. Phys., 7, 4639-4659, https://doi.org/10.5194/acp-74639-2007, 2007.

Freyer, H. D.: Seasonal trends of $\mathrm{NH}_{4}^{+}$and $\mathrm{NO}_{3}^{-}$nitrogen isotope composition in rain collected at Jülich, Germany, Tellus, 30, 8392, 1978.

Galloway, J. N., Dentener, F. J., Capone, D. G., Boyer, E. W., Howarth, R. W., Seitzinger, S. P., Asner, G. P., Cleveland, C., Green, P., and Holland, E.: Nitrogen cycles: past, present, and future, Biogeochemistry, 70, 153-226, 2004.

Gonfiantini, R.: Stable isotope reference samples for geochemical and hydrological investigations, Rep. Advis. Group, Vienna, 1984.

Gong, L., Lewicki, R., Griffin, R. J., Flynn, J. H., Lefer, B. L., and Tittel, F. K.: Atmospheric ammonia measurements in Houston, TX using an external-cavity quantum cascade laser-based sensor, Atmos. Chem. Phys., 11, 9721-9733, https://doi.org/10.5194/acp-11-9721-2011, 2011.

Heaton, T. H. E.: ${ }^{15} \mathrm{~N}^{14} \mathrm{~N}$ ratios of nitrate and ammonium in rain at Pretoria, South Africa, Atmos. Environ. 1967, 21, 843-852, 1987.

Hristov, A. N., Hanigan, M., Cole, A., Todd, R., McAllister, T. A., Ndegwa, P. M., and Rotz, A.: Review: ammonia emissions from dairy farms and beef feedlots, Can. J. Anim. Sci., 91, 1-35, 2011.
Hu, Q., Zhang, L., Evans, G. J., and Yao, X.: Variability of atmospheric ammonia related to potential emission sources in downtown Toronto, Canada, Atmos. Environ., 99 (Supplement C), 365-373, 2014.

Ianniello, A., Spataro, F., Esposito, G., Allegrini, I., Rantica, E., Ancora, M. P., Hu, M., and Zhu, T.: Occurrence of gas phase ammonia in the area of Beijing (China), Atmos. Chem. Phys., 10, 9487-9503, https://doi.org/10.5194/acp-10-9487-2010, 2010.

Kawashima, H. and Ono, S.: Nitrogen Isotope Fractionation from Ammonia Gas to Ammonium in Particulate Ammonium Chloride, Environ. Sci. Technol., 53, 10629-10635, 2019.

Koutrakis, P., Wolfson, J. M., and Spengler, J. D.: An improved method for measuring aerosol strong acidity: results from a ninemonth study in St Louis, Missouri and Kingston, Tennessee, Atmos. Environ. 1967, 22, 157-162, 1988.

Koutrakis, P., Sioutas, C., Ferguson, S. T., Wolfson, J. M., Mulik, J. D., and Burton, R. M.: Development and evaluation of a glass honeycomb denuder/filter pack system to collect atmospheric gases and particles, Environ. Sci. Technol., 27, 2497-2501, 1993.

Li, Y., Schwab, J. J., and Demerjian, K. L.: Measurements of ambient ammonia using a tunable diode laser absorption spectrometer: Characteristics of ambient ammonia emissions in an urban area of New York City, J. Geophys. Res.-Atmos., 111, D10S02, 2006.

Li, Y., Schichtel, B. A., Walker, J. T., Schwede, D. B., Chen, X., Lehmann, C. M. B., Puchalski, M. A., Gay, D. A., and Collett, J. L.: Increasing importance of deposition of reduced nitrogen in the United States, P. Natl. Acad. Sci. USA, 113, 5874-5879, 2016.

Livingston, C., Rieger, P., and Winer, A.: Ammonia emissions from a representative in-use fleet of light and medium-duty vehicles in the California South Coast Air Basin, Atmos. Environ., 43, 3326-3333, 2009.

McIlvin, M. R. and Altabet, M. A.: Chemical Conversion of Nitrate and Nitrite to Nitrous Oxide for Nitrogen and Oxygen Isotopic Analysis in Freshwater and Seawater, Anal. Chem., 77, 55895595, 2005.

Meng, Z. and Seinfeld, J. H.: Time scales to achieve atmospheric gas-aerosol equilibrium for volatile species, Atmos. Environ., 30, 2889-2900, 1996.

Meng, Z. Y., Lin, W. L., Jiang, X. M., Yan, P., Wang, Y., Zhang, Y. M., Jia, X. F., and Yu, X. L.: Characteristics of atmospheric ammonia over Beijing, China, Atmos. Chem. Phys., 11, 61396151, https://doi.org/10.5194/acp-11-6139-2011, 2011.

Miller, D. J., Wojtal, P. K., Clark, S. C., and Hastings, M. G.: Vehicle $\mathrm{NO}_{x}$ emission plume isotopic signatures: Spatial variability across the eastern United States, J. Geophys. Res.-Atmos., 122, 4698-4717, https://doi.org/10.1002/2016JD025877, 2017.

Nenes, A., Pandis, S. N., and Pilinis, C.: ISORROPIA: A new thermodynamic equilibrium model for multiphase multicomponent inorganic aerosols, Aquat. Geochem., 4, 123-152, 1998.

Nowak, J. B., Neuman, J. A., Bahreini, R., Middlebrook, A. M., Holloway, J. S., McKeen, S. A., Parrish, D. D., Ryerson, T. B., and Trainer, M.: Ammonia sources in the California South Coast Air Basin and their impact on ammonium nitrate formation, Geophys. Res. Lett., 39, L07804, https://doi.org/10.1029/2012GL051197, 2012.

Pan, Y., Gu, M., Song, L., Tian, S., Wu, D., Walters, W. W., Yu, X., Lü, X., Ni, X., and Wang, Y.: Systematic low bias 
of passive samplers in characterizing nitrogen isotopic composition of atmospheric ammonia, Atmos. Res., 243, 105018, https://doi.org/10.1016/j.atmosres.2020.105018, 2020.

Savard, M. M., Cole, A., Smirnoff, A., and Vet, R.: $\delta^{15} \mathrm{~N}$ values of atmospheric $\mathrm{N}$ species simultaneously collected using sectorbased samplers distant from sources - Isotopic inheritance and fractionation, Atmos. Environ., 162, 11-22, 2017.

Saylor, R. D., Edgerton, E. S., Hartsell, B. E., Baumann, K., and Hansen, D. A.: Continuous gaseous and total ammonia measurements from the southeastern aerosol research and characterization (SEARCH) study, Atmos. Environ., 44, 4994-5004, 2010.

Shah, V., Jaeglé, L., Thornton, J. A., Lopez-Hilfiker, F. D., Lee, B. H., Schroder, J. C., Campuzano-Jost, P., Jimenez, J. L., Guo, H., Sullivan, A. P., Weber, R. J., Green, J. R., Fiddler, M. N., Bililign, S., Campos, T. L., Stell, M., Weinheimer, A. J., Montzka, D. D., and Brown, S. S.: Chemical feedbacks weaken the wintertime response of particulate sulfate and nitrate to emissions reductions over the eastern United States, P. Natl. Acad. Sci. USA, 115, 8110-8115, 2018.

Skinner, R., Ineson, P., Jones, H., Sleep, D., and Theobald, M.: Sampling systems for isotope-ratio mass spectrometry of atmospheric ammonia, Rapid Commun. Mass Sp., 20, 81-88, 2006.

Smirnoff, A., Savard, M. M., Vet, R., and Simard, M.-C.: Nitrogen and triple oxygen isotopes in near-road air samples using chemical conversion and thermal decomposition, Rapid Commun. Mass Sp., 26, 2791-2804, 2012.

Suarez-Bertoa, R. and Astorga, C.: Impact of cold temperature on Euro 6 passenger car emissions, Environ. Pollut., 234, 318-329, 2018.

Sugahara, H., Takano, Y., Ogawa, N. O., Chikaraishi, Y., and Ohkouchi, N.: Nitrogen Isotopic Fractionation in Ammonia during Adsorption on Silicate Surfaces, ACS Earth Space Chem., 1, 2429, 2017.

Sun, K., Tao, L., Miller, D. J., Khan, M. A., and Zondlo, M. A.: OnRoad Ammonia Emissions Characterized by Mobile, Open-Path Measurements, Environ. Sci. Technol., 48, 3943-3950, 2014.

Sun, K., Tao, L., Miller, D. J., Pan, D., Golston, L. M., Zondlo, M. A., Griffin, R. J., Wallace, H. W., Leong, Y. J., Yang, M. M., Zhang, Y., Mauzerall, D. L., and Zhu, T.: Vehicle Emissions as an Important Urban Ammonia Source in the United States and China, Environ. Sci. Technol., 51, 2472-2481, 2017.

Sutton, M. A., Dragosits, U., Tang, Y. S., and Fowler, D.: Ammonia emissions from non-agricultural sources in the UK, Atmos. Environ., 34, 855-869, 2000.

Sutton, M. A., Erisman, J. W., Dentener, F., and Möller, D.: Ammonia in the environment: from ancient times to the present, Environ. Pollut., 156, 583-604, 2008.

Updyke, K. M., Nguyen, T. B., and Nizkorodov, S. A.: Formation of brown carbon via reactions of ammonia with secondary organic aerosols from biogenic and anthropogenic precursors, Atmos. Environ., 63, 22-31, 2012.

Urey, H. C.: The thermodynamic properties of isotopic substances, J. Chem. Soc., 7, 562-581, 1947.
U.S. Department of Transportation: Major truck routes on the NHS 2011, Federal Highway Administration, Office of Freight Management and Operations, freight analysis framework, version 3.4, 2013.

Van Damme, M., Clarisse, L., Whitburn, S., Hadji-Lazaro, J., Hurtmans, D., Clerbaux, C., and Coheur, P.-F.: Industrial and agricultural ammonia point sources exposed, Nature, 564, 99-103, 2018.

Walters, W.: Data for "Constraining Ammonia Emissions in TrafficDerived Plumes Utilizing Nitrogen Stable Isotopes”, Brown University Open Data Collection. Brown Digital Repository, Brown University Library, https://doi.org/10.26300/q3h4-7s93, 2020.

Walters, W. W. and Hastings, M. G.: Collection of Ammonia for High Time-Resolved Nitrogen Isotopic Characterization Utilizing an Acid-Coated Honeycomb Denuder, Anal. Chem., 90, 8051-8057, 2018.

Walters, W. W., Chai, J., and Hastings, M. G.: Theoretical Phase Resolved Ammonia-Ammonium Nitrogen Equilibrium Isotope Exchange Fractionations: Applications for Tracking Atmospheric Ammonia Gas-to-Particle Conversion, ACS Earth Space Chem., 3, 79-89, 2018.

Walters, W. W., Blum, D. E., and Hastings, M. G.: Selective Collection of Particulate Ammonium for Nitrogen Isotopic Characterization Using a Denuder-Filter Pack Sampling Device, Anal. Chem., 91, 7586-7594, 2019.

Wang, J. M., Jeong, C.-H., Zimmerman, N., Healy, R. M., and Evans, G. J.: Real world vehicle fleet emission factors: Seasonal and diurnal variations in traffic related air pollutants, Atmos. Environ., 184, 77-86, 2018.

Wang, S., Nan, J., Shi, C., Fu, Q., Gao, S., Wang, D., Cui, H., SaizLopez, A., and Zhou, B.: Atmospheric ammonia and its impacts on regional air quality over the megacity of Shanghai, China, Sci. Rep.-UK, 5, 15842, https://doi.org/10.1038/srep15842, 2015.

Whitehead, J. D., Longley, I. D., and Gallagher, M. W.: Seasonal and Diurnal Variation in Atmospheric Ammonia in an Urban Environment Measured Using a Quantum Cascade Laser Absorption Spectrometer, Water Air Soil Poll., 183, 317-329, 2007.

Xiao, H.-W., Xiao, H.-Y., Long, A.-M., and Liu, C.-Q.: $\delta^{15} \mathrm{NNH}_{4}^{+}$ variations of rainwater: Application of the Rayleigh model, Atmospheric Res., 157, 49-55, 2015.

Yu, X.-Y., Lee, T., Ayres, B., Kreidenweis, S. M., Collett Jr., J. L., and Malm, W.: Particulate Nitrate Measurement Using Nylon Filters, JAPCA J. Air Waste Ma., 55, 1100-1110, 2005.

Yu, X.-Y., Lee, T., Ayres, B., Kreidenweis, S. M., Malm, W., and Collett, J. L.: Loss of fine particle ammonium from denuded nylon filters, Atmos. Environ., 40, 4797-4807, 2006.

Zhang, L., Altabet, M. A., Wu, T., and Hadas, O.: Sensitive measurement of $\mathrm{NH}_{4}^{+15} \mathrm{~N} /{ }^{14} \mathrm{~N}\left(\delta^{15} \mathrm{NH}_{4}^{+}\right)$at natural abundance levels in fresh and saltwaters, Anal. Chem., 79, 5297-5303, 2007.

Zhang, Y., Tang, A., Wang, D., Wang, Q., Benedict, K., Zhang, L., Liu, D., Li, Y., Collett Jr., J. L., Sun, Y., and Liu, X.: The vertical variability of ammonia in urban Beijing, China, Atmos. Chem. Phys., 18, 16385-16398, https://doi.org/10.5194/acp-18-163852018, 2018. 